WSRC-TR-94-0234

Keywords: glass, vitrification, hazardous waste, mixed waste, thermal treatment, stabilization, solidification

\title{
VITRIFICATION OF M-AREA MIXED (HAZARDOUS AND RADIOACTIVE) F006 WASTES: I. SLUDGE AND SUPERNATE CHARACTERIZATION (U)
}

\author{
C. M. Jantzen and J.B. Pickett
}

Approved by

R.H. Spires, Research Manager

Immobilization Technology Section

Publication Date: September 1, 2001 
This document was prepared in conjunction with work accomplished under Contract No. DE-AC09-96SR18500 with the U.S. Department of Energy

\section{DISCLAIMER}

This report was prepared as an account of work sponsored by an agency of the United States Government. Neither the United States Government nor any agency thereof, nor any of their employees, makes any warranty, express or implied, or assumes any legal liability or responsibility for the accuracy, completeness, or usefulness of any information, apparatus, product or process disclosed, or represents that its use would not infringe privately owned rights. Reference herein to any specific commercial product, process or service by trade name, trademark, manufacturer, or otherwise does not necessarily constitute or imply its endorsement, recommendation, or favoring by the United States Government or any agency thereof. The views and opinions of authors expressed herein do not necessarily state or reflect those of the United States Government or any agency thereof.

This report has been reproduced directly from the best available copy.

Available for sale to the public, in paper, from U.S. Department of Commerce, National Technical Information Service, 5285 Port Royal Road, Springfield, VA 22161

phone: (800) 553-6847

fax: (703) 605-6900

email: orders@ntis.fedworld.gov

online ordering: http://www.ntis.gov/support/index.html

Available electronically at http://www.doe.gov/bridge

Available for processing fee to U.S. Department of Energy and its contractors, in paper, from: U.S. Department of Energy, Office of Scientific and Technical Information, P.O. Box 62, Oak Ridge, TN 37831-0062, phone: (865) 576-8401, fax: (865) 576-5728, email: reports@adonis.osti.gov 


\section{EXECUTIVE SUMMARY}

Solidification of Resource Conservation and Recovery Act (RCRA) "listed" mixed (hazardous and radioactive) wastes that were generated in the Savannah River Site's (SRS) M-Area facility were recently vitrified into borosilicate glass. The initial concept of solidification into glass began in 1987 when the sludge and supernates reported in this study were first analyzed at the Savannah River Technology Center (SRTC). A year later, the SRTC Professional Planning Committee (PPC) recommended that high nitrate containing (low-level) wastes, such as those existing in M-Area, be considered for vitrification. The investigation into vitrification of low-level high nitrate containing wastes was considered timely because of the potential for large waste volume reduction compared to alternative solidification into cement. Glass formulations were proposed by SRTC in the 1990-1994 timeframe and were used as the basis for privatization of a vitrification Vendor Treatment Facility (VTF).

The M-Area operations at the Savannah River Site (SRS) in Aiken, South Carolina, produced reactor components for nuclear weapons materials for the U.S. Department of Energy. The resulting waste was stored in nine tanks. The total volume in storage was initially $\sim 1,200,000$ gallons of which $\sim 1 / 3$ was a gelatinous hydroxide sludge. The supernate in the tanks was treated in a wastewater treatment facility and the resulting effluent released to a National Pollution Discharge Elimination System (NPDES) permitted outfall stream on the SRS site. There was approximately 425,000 gallons of waste sludge, which contained high concentrations of aluminum, sodium, uranium, and nitrate. The sludge was mixed with 275,000 gallons of spent $\mathrm{SiO}_{2}$ rich filter aids. During the ensuing years of wastewater treatment of the supernate the type of filter aid varied from diatomaceous earth to perlite and/or perflo. All the filter aids were $\mathrm{SiO}_{2}$ enriched and were of high surface area.

Vitrification into borosilicate glass was chosen as the preferred stabilization option because it reduced the volume of sludge by $\sim 85 \%$ and reduced the final disposal volume by $96 \%$ compared to alternative stabilization technologies. The large volume reduction will allow for large associated savings in disposal and/or long term storage costs once the vitrified waste form is delisted.

The techniques used to chemically analyze the waste sludge, supernate, spent filter aid, and a "crust" that formed on the settled sludge solids are documented in this study. The analytic methods used to identify the phases present in the waste sludge are also detailed. All supernate chemical analyses were assessed for accuracy and consistency by performing mass balance calculations on the species in solution. All sludge chemical analyses were assessed for accuracy and consistency by performing mass balance calculations on the species identified by $\mathrm{x}$-ray diffraction.

Zeolite-A was identified in the sludges when no zeolite had ever been used in the M-Area processes. Experiments were performed in this study to demonstrate that the Zeolite-A formed in-situ in the tanks at ambient temperature from reaction of the silica containing filter aids and the aluminate rich waste in a high caustic environment. 
This page intentionally left blank. 


\section{TABLE OF CONTENTS}

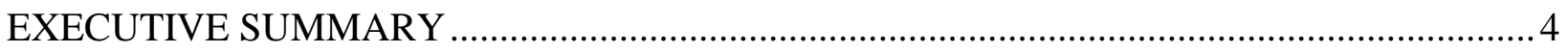

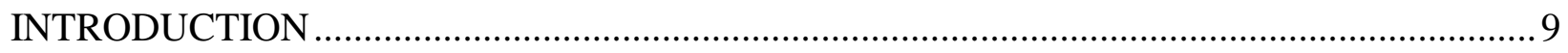

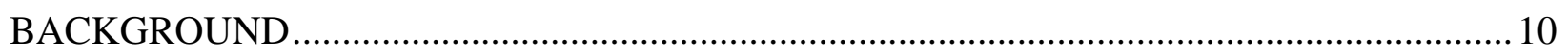

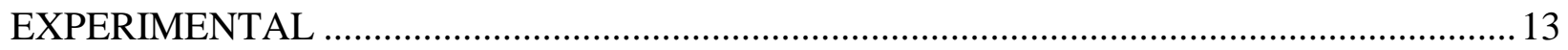

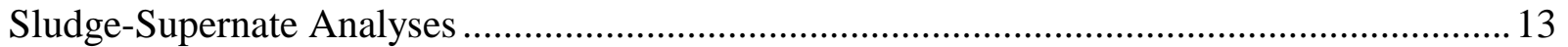

Sludge Analyses (Tanks 1-6 and Tank 8) ......................................................................... 14

Sludge Crust (Tank 8) .................................................................................................. 15

Sludge and Spent Filter Aid Analyses (Tank 7 and Tank 10) ............................................ 15

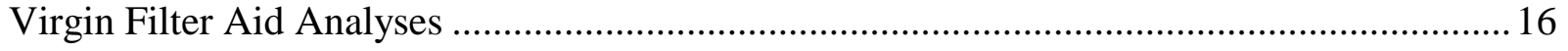

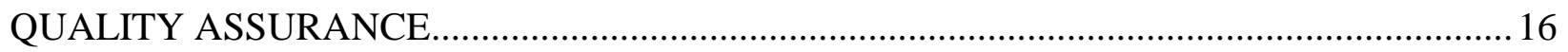

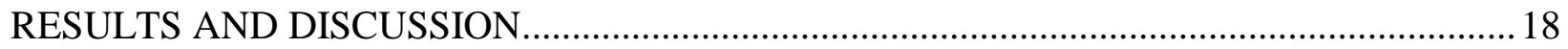

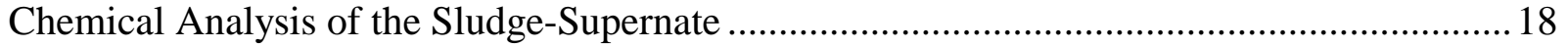

Chemical Analysis of Sludge and Spent Filter Aids ..................................................... 18

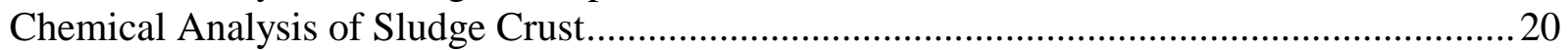

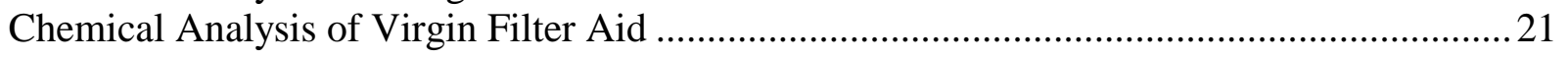

IDENTIFICATION OF PHASE CONSTITUENTS IN M-AREA SLUDGE AND CRUST.......21

IDENTIFICATION OF IN-TANK ZEOLITE FORMATION ..............................................2 29

MASS BALANCE CALCULATIONS ......................................................................... 31

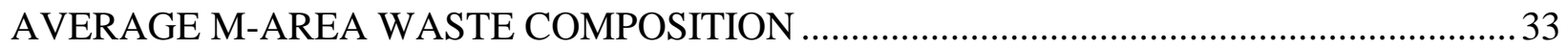

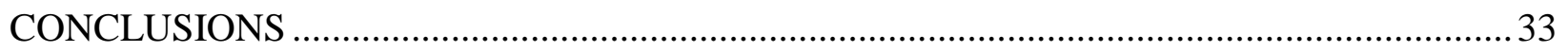

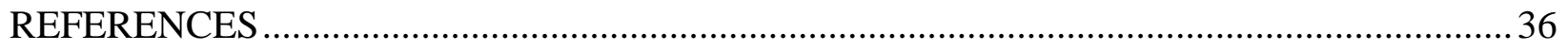

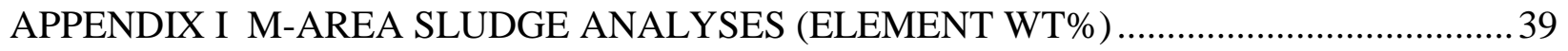

APPENDIX II M-AREA VIRGIN FILTER AID ANALYSES ...........................................51 


\section{LIST OF FIGURES}

Figure 1. Schematic of the M-Area mixed waste solidification process................................. 11

Figure 2. X-ray diffraction pattern of the M-Area sludge dried at $90^{\circ}$ overnight. ....................227

Figure 3. X-ray diffraction pattern of the M-Area sludge heat treated at $300^{\circ} \mathrm{C}$ and $600^{\circ} \mathrm{C} \ldots \ldots . .27$

Figure 4. X-ray analysis of untreated (virgin) perflo and diatomaceous earth compared to treatment with $6 \mathrm{M} \mathrm{NaOH}$ for 29 hours at room temperature which crystallized $\mathrm{Na}_{2} \mathrm{SiO}_{3}$ and sodalite (a mineral related in structure to Zeolite-A).

\section{LIST OF TABLES}

Table I. Comparative Volume Reductions for M-Area Waste Stabilization.

Table II. M-Area Tank Inventories as of April, 1994

Table III. Detection Limits of Analytic Instrumentation

Table IV. Analyses of M-Area Waste Slurry (Sludge + Supernate)

Table V. Summary of M-Area Sludge Analyses and Mass Balance Calculations

Table VI. Summary of M-Area Crust Analyses from Tank 8

Table VII. Summary of M-Area Filter Aid Analyses

Table VIII. X-Ray Diffraction Phase Identification and Relative Concentrations of the Species in M-Area Sludge and Spent Filter Aid

Table IX. Example of Mass Balance Calculation for M-Area Sludge (Tank 1)

Table X. Measured wt\% Solids and Specific Gravity of M-Area Tank Wastes

Table XI. M-Area Calculated Composite Sludge/Residual Supernate Composition. ${ }^{\dagger}$ 


\title{
VITRIFICATION OF M-AREA MIXED (HAZARDOUS AND RADIOACTIVE) F006 WASTES: I. SLUDGE AND SUPERNATE CHARACTERIZATION
}

\author{
C.M. Jantzen and J.B. Pickett \\ Savannah River Technology Center \\ Westinghouse Savannah River Company \\ Aiken, SC 29803
}

\section{INTRODUCTION}

Technologies are being developed by the US Department of Energy's (DOE) Nuclear Facility sites to convert low-level and mixed (hazardous and radioactive) wastes to a solid stabilized waste form for permanent disposal. One of the alternative technologies is vitrification into a borosilicate glass waste form. The Environmental Protection Agency (EPA) has declared vitrification the Best Demonstrated Available Technology (BDAT) for high-level radioactive mixed waste ${ }^{1}$ and produced a Handbook of Vitrification Technologies for Treatment of Hazardous and Radioactive Waste. ${ }^{2}$ The DOE Office of Technology Development (OTD) has taken the position that mixed waste needs to be stabilized to the highest level reasonably possible to ensure that the resulting waste forms will meet both current and future regulatory specifications. Stabilization of low level and hazardous wastes in glass are in accord with the 1988 Savannah River Technology Center (SRTC), then the Savannah River Laboratory (SRL), Professional Planning Committee (PPC) recommendation ${ }^{3}$ that high nitrate containing (low-level) wastes be incorporated into a low temperature glass (via a sol-gel technology). The investigation into this new technology was considered timely because of the potential for large waste volume reduction compared to solidification into cement.

Vitrification produces durable waste forms at volume reductions up to $97 \%{ }^{4}$ Large reductions in volume minimize long-term storage costs, making vitrification a cost effective technology on a life cycle basis. ${ }^{5}$ The US DOE Savannah River Site (SRS), which is operated by Westinghouse Savannah River Company (WSRC), investigated vitrification for disposal of various low-level and mixed wastes. ${ }^{4} 6$ The first /mixed wastes vitrified in laboratory studies at SRS were the MArea nickel plating line wastes reported in this study.

The M-Area operations at the SRS in Aiken, South Carolina, produced reactor components for nuclear weapons materials for the U.S. Department of Energy. The mixed waste resulting from these operations was a listed Resource Conservation and Recovery Act (RCRA) F006 waste which was stored in the M-Area Process Waste Interim Treatment/Storage Facility (PWIT/SF). The total volume in storage was initially $\sim 1,200,000$ gallons of which $\sim 33 \%$ was a gelatinous hydroxide sludge containing high concentrations of aluminum, sodium, uranium, and nitrate plus the RCRA metal of concern, nickel. It had been demonstrated ${ }^{7,8}$ that a volume reduction of 65 $70 \%$ of the M-Area stored waste could be achieved by wastewater treatment of the supernate, with the resulting effluent released via a permitted National Pollution Discharge Elimination

\footnotetext{
$\ddagger$ a wastewater treatment sludge from electroplating operations
} 
System (NPDES) outfall. About 275,000 gallons of spent $\mathrm{SiO}_{2}$ rich filter aids (perlite/perflo) were generated from the supernate treatment.

In January 1989 South Carolina Department of Health and Environmental Control (SCDHEC) approved a construction permit for the DETF Supernate Transfer Facility. In May 1990 the DETF received a permit to operate the DETF. This allowed the DETF to be used to treat the supernate from the M-Area Interim Treatment/Storage Facility (IT/SF) tanks. There were six 35,000 gallon tanks (Tanks 1-6) and three 500,000 gallon tanks (Tanks 7, 8, 10). Tank 10 was filled with the spent filter aid. Treatment of the supernate from Tank 8 was completed in November 1992. Treatment of the supernate from Tank 7 was completed in October 1993. Treatment of the supernate in Tanks 1 through Tank 6 was completed in June 1994. The sludge from Tanks 1-8 and spent filter aid from Tank 10 were mixed together prior to final stabilization (Figure 1).

Comparisons of the waste volume reduction achieved by vitrification compared to alternative stabilization strategies in cement (Table I and Figure 1) shows that vitrification of M-Area composite waste (Option 3) reduces the stabilized volume by $96 \%$ relative to the base case cement stabilization. Volume reductions on the order of $\sim 86 \%$ can be achieved by mixing portland cement with the homogenized waste, followed by pressure filtration and rinsing. This low volume cementation process has been designated FIST for FIltration and STabilization (Option 2). ${ }^{7.8}$

\section{BACKGROUND}

The Liquid Effluent Treatment Facility (LETF) was constructed in 1985 to process M-Area chemical wastes due to the federally mandated closure of the M-Area seepage basin. The LETF consisted of three facilities: the Dilute Effluent Treatment Facility (DETF), the Chemical Transfer Facility (CTF), and the Interim Treatment/Storage Facility (IT/SF). The DETF processed dilute wastewaters from the M-Area processes and released the clarified liquid to Tim's Branch.' The DETF was a conventional water treatment facility which used precipitation, flocculation, and filtration to remove dissolved metals. These solids were transferred through the Chemical Transfer Facility (CTF) to the IT/SF.

In May 1990 South Carolina Department of Health and Environmental Control (SCDHEC) approved a permit to operate the DETF-IST Supernate Transfer Facility. ${ }^{9}$ The permit allowed the DETF to be used to treat the supernate from the M-Area Interim Treatment/Storage Facility (IT/SF) tanks. When the DETF-IST Supernate Transfer Facility concept for treatment of MArea's supernate and subsequent discharge to Tim's branch was initiated, M-Area's waste solidification strategy was altered from solidification of sludge plus supernate to solidification of only the sludge and spent filter aid. Supernate treatment was completed in 1994. The current tank inventory of sludge in gallons is shown in Table II. Note that minor residual supernate volumes are associated with the sludge residues in each tank (Table II). 


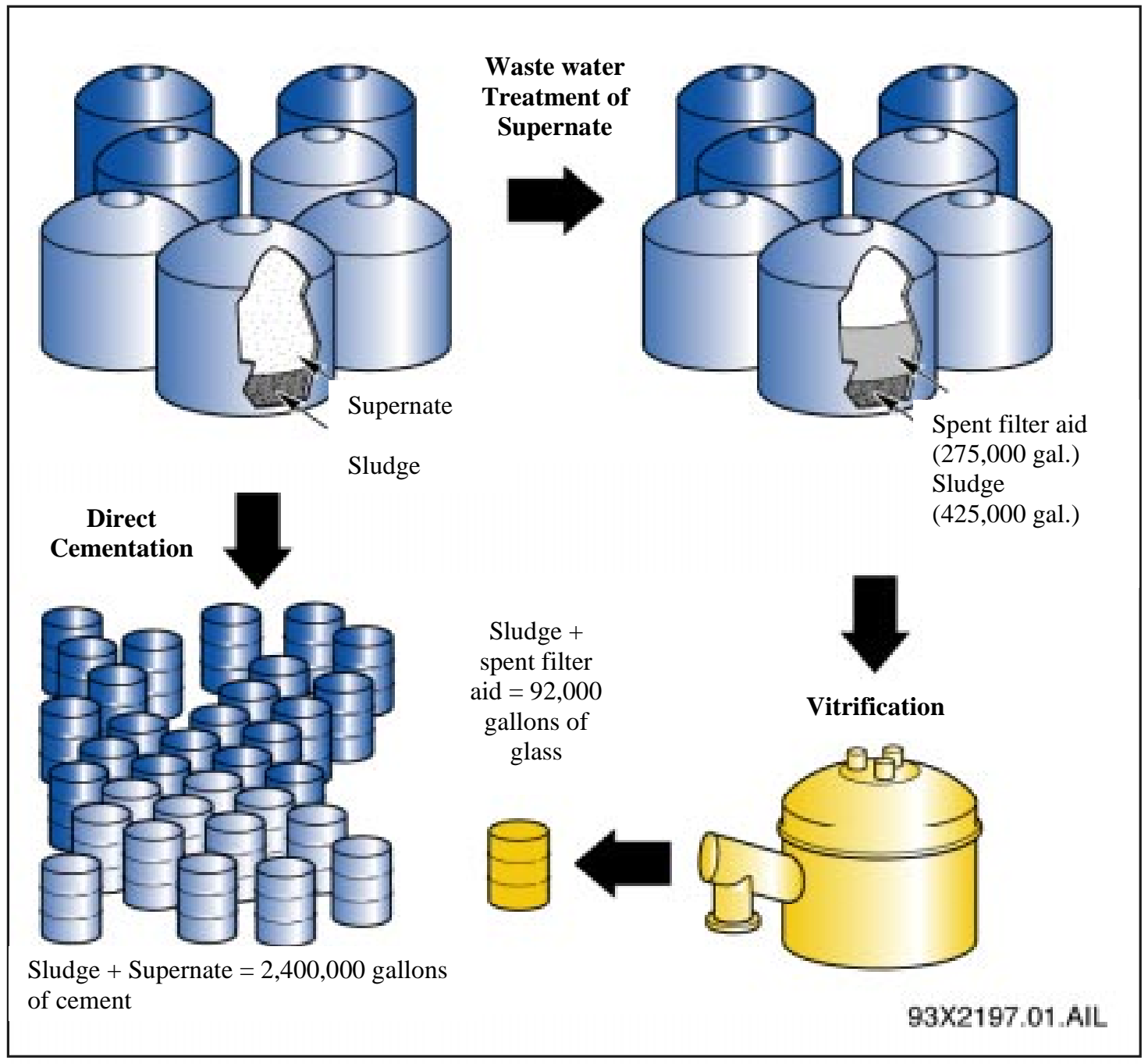

Figure 1. Schematic of the M-Area mixed waste solidification process. Large volume reductions can be achieved by combining wastewater treatment with vitrification instead of stabilization of sludge plus supernate in cement, e.g. 92,000 gallons of glass equals $\sim 1673$ drums (55-gallon size) while 2,400,000 gallons of cement makes 43,636 drums. This is a ratio of 1 drum of glass to every 26 drums of cement. 
Table I. Comparative Volume Reductions for M-Area Waste Stabilization.

\begin{tabular}{|c|c|}
\hline Stabilization Options & $\begin{array}{c}\text { Volume } \\
\text { Reduction }\end{array}$ \\
\hline $\begin{array}{c}\text { Base Case (CEMENT WITH SUPERNATE) } \\
\text { 1,200,000 gallons of M-Area supernate + sludge } \\
2,400,000 \text { gallons cement }\end{array}$ & $0 \%$ \\
\hline $\begin{array}{c}\text { Option 1 (CEMENT WITHOUT SUPERNATE) } \\
700,000 \text { gallons sludge + spent filter aid + cement } \\
=1,400,000 \text { gallons cement }\end{array}$ & $42 \%$ \\
\hline $\begin{array}{c}\text { Option 2 (LOW VOLUME CEMENT USING FIST) } \\
700,000 \text { gallons wastewater treated sludge/spent filter aid + } \\
\text { cement }=325,000 \text { gallons cement }\end{array}$ & $86 \%$ \\
\hline $\begin{array}{c}\text { Option 3 (VITRIFICATION) } \\
700,000 \text { gallons wastewater treated sludge + spent filter aid } \\
=92,000 \text { gallons glass }\end{array}$ & $96 \%$ \\
\hline
\end{tabular}

* Relative to original 2,400,000 gallons grout projected if the sludge is not wastewater treated

The M-Area sludge and spent filter aid waste was solidified by vitrification in a Vendor Treatment Facility (VTF) in M-Area in 1996-1999. ${ }^{10}$ A delisting petition for the vitrified waste has been submitted to EPA and is still under consideration. This would allow the vitrified waste to be disposed of in the SRS burial ground. If the vitrified waste is not delisted then the waste form will remain a RCRA listed waste and disposal in a permitted RCRA mixed waste repository will be necessary.

Samples of M-Area sludge and supernate were obtained in September 1986 from Tank 6 and 8 were being agitated at that time. Sludge samples from Tanks 1 through 6, and Tank 8 were obtained in January of 1988 after the agitatiors had been shut off for $~ 2$ years. Analyses of these tank samples were previously documented. ${ }^{11}$ Sludge samples from Tank 7 and filter aid samples from Tank 10 were obtained in March of 1992. Additional filter aid from Tank 10 was obtained in November of 1992. The sludge, supernate, and filter aid characterization documented in this study was completed so that durable and processable glass compositions could be formulated ${ }^{12}$ and a waste treatability study ${ }^{13}$ performed at SRTC to support the vitrification in a Vendor Treatment Facility (VTF). 
Sludge Analyses (Tanks 1-6 and Tank 8)

Sludge samples from IT/SF Tanks 1-6 and Tank 8 were obtained in January 1988. The supernate was decanted off each sample. The wt\% solids were obtained in duplicate from samples dried at $105^{\circ} \mathrm{C}$. Additional samples were dried overnight at $90^{\circ} \mathrm{C}$ to obtain $\mathrm{x}$-ray diffraction (XRD) analyses of the crystalline species. Drying at $90^{\circ} \mathrm{C}$ evaporates adsorbed water but does not evaporate water of crystallization of hydrated species. In cases where precursor, poorly crystallized phases were observed in the XRD spectra, the samples were sequentially heated at $300^{\circ} \mathrm{C}$ and $600^{\circ} \mathrm{C}$ to crystallize the poorly formed phase(s) and aid in phase identification and mass balance calculations.

The sludge was dried at $\sim 300^{\circ} \mathrm{C}$ to remove both residual hydroxide species and waters of hydration. Dried sludge compositions were determined in duplicate in March, 1988 and in duplicate in November 1988 because the $\mathrm{Ni}$ and $\mathrm{K}$ analyses had been omitted from the March analyses. Moreover, the $\mathrm{HCl} / \mathrm{HF}$ dissolution had been used to determine Si by AA in March and this number was biased higher than the ICP analysis for Si. This bias was attributed to the HF dissolving $\mathrm{Si}$ from the glass bead in the nebulizer of the AA. Silica was redetermined by AA from the $\mathrm{Na}_{2} \mathrm{O}_{2}$ dissolution in November 1988 .

Different ICP instruments were used for the March 1988 and November 1988 analyses. The detection limits for each of these instruments is listed in Table III . The major elements (K, Na, $\mathrm{Ca}, \mathrm{Mg}, \mathrm{Si}, \mathrm{Al}$, and $\mathrm{Fe}$ ) are accurate to within $\pm 10 \%$ at concentrations $>1 \mathrm{ppm}$. Within a factor of two of the detection limits listed (Table III), the precision of any element is only $\pm 100 \%$.

The dried sludge was completely analyzed by the following techniques:

- Dissolution by $\mathrm{Na}_{2} \mathrm{O}_{2}$ with an $\mathrm{HCl}$ uptake

- ICP for Al, Ca, Fe, Mg, Mn, Li, Si, Cr, B, Sr, Ti, P, Ba, Pb, Mo, Zn, Cu (March and November 1988)

- AA for Si (November 1988)

- $\quad$ Dissolution by $\mathrm{HCl} / \mathrm{HF}$ bomb

- ICP for Na, Ni, Zr (November 1988)

- AA for Ni due to Ni interferences on ICP in the presence of U (November, 1988)

- AA for $\mathrm{Na}$ (March and November 1988)

- AA for K (November 1988)

- AA for Si (March 1988)

- Uranium by Davis-Gray titration (March 1988)

- Dissolution by $\mathrm{Na}_{2} \mathrm{O}_{2}$ with a $\mathrm{H}_{2} \mathrm{O}$ uptake

- IC for $\mathrm{SO}_{4}, \mathrm{NO}_{3}, \mathrm{PO}_{4}$ (March 1988)

- ISE for $\mathrm{Cl}$ and $\mathrm{F}$ (March 1988) 


\section{Sludge Crust (Tank 8)}

A layer of white crystalline material was found to have formed on the surface of the sludge in Tank 8. This layer separated the sludge from the supernate and was thought to have precipitated from the supernate. The same crust was identified in most of the M-Area tanks but only one sample was analyzed. The crust varied from 9.51 to $12.7 \mathrm{~mm}$ (3/8 to $1 / 2 \mathrm{inch})$. A small slab of crust from Tank 8 was received for analysis in early 1989. The sample was chemically analyzed in triplicate using the same techniques as used for the sludge analyses for Tank 8. The sample phases were also identified by XRD and the sample was examined by Scanning Electron Microscopy (SEM).

Sludge and Spent Filter Aid Analyses (Tank 7 and Tank 10)

Sludge samples from IT/SF Tank 7 and Tank 10 were obtained in March 1992. A second larger sample of Tank 10 was obtained in November 1992 that was more representative of the contents of Tank 10. For each tank the wt\% solids were obtained in duplicate from samples dried at $105^{\circ} \mathrm{C}$. Tank 7 and 10 samples were dried overnight at $90^{\circ} \mathrm{C}$ to obtain $\mathrm{x}$-ray diffraction (XRD) analyses of the crystalline species without driving off any hydroxide species. In cases where broad poorly crystallized diffraction peaks were observed in the XRD spectra, the samples were heat treated at $600^{\circ} \mathrm{C}$ to crystallize the poorly formed phase(s) and aid in phase identification.

The chemical analyses of the sludge compositions were determined in duplicate. The sludge was dried at $\sim 300^{\circ} \mathrm{C}$ to remove residual hydroxide species and completely analyzed for the remaining cations and ions by the following techniques:

- Dissolution by $\mathrm{Na}_{2} \mathrm{O}_{2}$ with an $\mathrm{HCl}$ uptake

- ICP for Al, Ca, Fe, Mg, Mn, Li, Si, Cr, B, Sr, Ti, P, Ba, Pb, Mo, Zn, Cu

- AA for $\mathrm{Si}$

- Dissolution by $\mathrm{HCl} / \mathrm{HF}$ bomb

- ICP for $\mathrm{Na}, \mathrm{Ni}, \mathrm{Zr}$

- AA for $\mathrm{Ni}, \mathrm{Na}, \mathrm{K}, \mathrm{Si}$

- Uranium by ChemCheck

- Dissolution by $\mathrm{Na}_{2} \mathrm{O}_{2}$ with a $\mathrm{H}_{2} \mathrm{O}$ uptake

- IC for $\mathrm{SO}_{4}, \mathrm{NO}_{3}, \mathrm{PO}_{4}$

- ISE for $\mathrm{Cl}$ and $\mathrm{F}$ 


\section{Virgin Filter Aid Analyses}

Perflo, perlite, and diatomaceous earth are high silica containing additives used in M-Area processing. Samples of these additives, which are oxide based, were analyzed only for cations in November 1988. Additional perlite and perflo were analyzed in February, 1993. The following techniques were used:

- $\mathrm{H}_{2} \mathrm{O}$ content by drying at $600^{\circ} \mathrm{C}$ overnight

- Dissolution by $\mathrm{Na}_{2} \mathrm{O}_{2}$ with an $\mathrm{HCl}$ uptake

- ICP for Al, Ca, Fe, Mg, Mn, Li, Si, Cr, B, Sr, Ti, P, Ba, Pb, Mo, Zn, Cu

- Dissolution by $\mathrm{HCl} / \mathrm{HF}$ bomb

- ICP for $\mathrm{Na}, \mathrm{Ni}, \mathrm{Zr}$

- AA for $\mathrm{Ni}, \mathrm{Na}, \mathrm{K}$

XRD analyses were also performed on perflo and diatomaceous earth both before and after chemical treatment with $\mathrm{NaOH}$ in order to determine if chemical alteration of these additives was occurring due to the high $\mathrm{pH}$ environment in the IT/SF storage tanks. The filter aids were analyzed by XRD before chemical treatment. The filter aids were then treated with $6 \mathrm{M} \mathrm{NaOH}$ solution for 29 hours, filtered, dried at $80^{\circ} \mathrm{C}$ overnight, dried an additional 1.5 hours at $200^{\circ} \mathrm{C}$, and the XRD analysis repeated.

\section{QUALITY ASSURANCE}

All analyses were conducted at Savannah River Technology Center (SRTC) in accordance with DOE/RW-0214 and ASME NQA-1 based quality assurance program in use at the time the work was performed. The analytic results are recorded in laboratory notebooks DPSTN-4475, DPSTN-4725, and DPSTN-4695. The data and calculations from this report were used in the Vendor Design Specification Number X-SPP-M-0001, Revision 5. For this reason all of the calculations were verified by Glenn Diener and documented in calculation package Q-CLC-M94012 on May 31, 1994 and accepted by John B. Pickett on June 11, 1994. 
Table III. Detection Limits of Analytic Instrumentation

\begin{tabular}{lccc} 
Element & $\begin{array}{c}\text { December 1986- } \\
\text { October 1988 } \\
\text { ppm (Ref. 14) }\end{array}$ & $\begin{array}{c}\text { November 1988- } \\
\text { present } \\
\text { ppm (Ref. 15) }\end{array}$ & Technique \\
\hline $\mathrm{Al}$ & 0.09 & 0.025 & ICP \\
$\mathrm{Ca}$ & 0.03 & 0.0001 & ICP \\
$\mathrm{Cu}$ & 0.02 & 0.003 & ICP \\
$\mathrm{Fe}$ & 0.01 & 0.004 & ICP \\
$\mathrm{K}$ & 0.005 & 0.005 & AA \\
$\mathrm{Mg}$ & 0.003 & 0.0001 & ICP \\
$\mathrm{Na}$ & 0.06 & 0.025 & ICP \\
$\mathrm{P}$ & 0.04 & 0.03 & ICP \\
$\mathrm{Pb}$ & 0.07 & 0.05 & ICP \\
$\mathrm{Ru}$ & 0.02 & ICP \\
$\mathrm{Si}$ & 0.03 & 0.025 & ICP \\
$\mathrm{Ti}$ & 0.002 & 0.02 & ICP \\
$\mathrm{Zr}$ & 0.003 & \\
\hline
\end{tabular}




\title{
RESULTS AND DISCUSSION
}

\author{
Chemical Analysis of the Sludge-Supernate
}

Samples of agitated sludge-supernate slurry from IT/SF Tanks 6 and 8 were dissolved in $\mathrm{HNO}_{3}$ as described previously and analyzed. The $\mathrm{pH}$ of the slurry varied from 11.90-12.25 (Table IV). The specific gravity was $\sim 1.10 \mathrm{~g} / \mathrm{mL}$ while the wt $\%$ solids varied from 10.22 to 11.05 . The sludge-supernate slurry contains high concentrations of sodium, nitrate, phosphate and aluminum (Table IV).

The cation analyses by ICP are given in Table IV. Sodium analyzed by ICP and AA gave comparable results (Table IV). Uranium analyses were determined by Davis-Gray titration even though the concentrations were $<1 \mathrm{~g} / \mathrm{L}$ because significant quantities of other redox species were not present in the slurry (Table IV). The uranium concentrations were low enough not to cause spectral interferences. This allowed $\mathrm{Ni}, \mathrm{Pb}$, and $\mathrm{Zn}$ to be determined by ICP analysis.

Acid soluble $\mathrm{PO}_{4}$, was analyzed as $\mathrm{P}$ by ICP on the acidified sludge-supernate samples. Water soluble $\mathrm{PO}_{4}$ was measured by IC and is lower than the acid soluble $\mathrm{PO}_{4}$ values listed in Table IV. This implies that water soluble $\mathrm{PO}_{4}$ is a major constituent of the supernate and that a $\mathrm{PO}_{4}$ containing solid is a major constituent of the sludge portion of the slurry. The remaining water soluble anions were analyzed by IC while the $\mathrm{CO}_{3}$ of the samples was analyzed by a precipitation-titration technique.

From the analyses in Table IV, the major elements in the slurry are $\mathrm{Na}, \mathrm{Al}, \mathrm{NO}_{3}$, and $\mathrm{PO}_{4}$. At $\mathrm{pH}$ values $>11$ the stable $\mathrm{Al}$ species is $\mathrm{AlO}_{2}$ and at $\mathrm{pH}$ values $>12$ the major $\mathrm{P}$ species is $\mathrm{PO}_{4}{ }^{16}$ The major aqueous species in the supernate-sludge at $\mathrm{pH}$ values of $\sim 12$ are $\mathrm{NaNO}_{3}, \mathrm{NaAlO}_{2}$, and $\mathrm{Na}_{3} \mathrm{PO}_{4}$. A molar anion-cation mass balance based on this speciation is shown at the bottom of Table IV. The mass balance shows excellent agreement and consistency in the analyses performed.

\section{Chemical Analysis of Sludge and Spent Filter Aids}

The chemical analysis of the M-Area sludge (Tanks 1 through 6 and 8) was initially determined in duplicate in March 1988 and a second set of duplicate analyses performed in November 1988. Chemical analysis of sludge from Tank 7 and spent filter aid from Tank 10 was performed in May 1992. The Tank 10 chemical analysis was repeated on a more representative sample in July 1993. The data is summarized in Table V and the replicate analyses for each tank are given in Appendix I. Different ICP units were used for the March 1988 and November 1988 analyses and this accounts for some of the variation in detection limits and some of the large standard deviations (Appendix I). 
Table IV. Analyses of M-Area Waste Slurry (Sludge + Supernate)

\begin{tabular}{|c|c|c|c|}
\hline Constituent (Analysis Method) & $\begin{array}{c}\text { IT/SF-Tank } 6 \\
(\mathrm{gm} / \mathrm{L})\end{array}$ & $\begin{array}{c}\text { IT/SF Tank } 8 \\
\text { Replicate A } \\
\text { (gm/L) }\end{array}$ & $\begin{array}{c}\text { IT/SF Tank 8 } \\
\text { Replicate B } \\
\text { (gm/L) }\end{array}$ \\
\hline \multicolumn{4}{|l|}{ CATIONS AND ANIONS } \\
\hline Uranium (D-G titration) & 0.596 & 0.090 & 0.070 \\
\hline Sodium (ICP) & 36.327 & 36.054 & 34.616 \\
\hline Sodium (AA) & 31.253 & 37.228 & 36.308 \\
\hline Aluminum (ICP) & 3.57 & 3.28 & 2.23 \\
\hline Calcium (ICP) & 0.045 & 0.011 & 0.010 \\
\hline Iron (ICP) & 0.048 & 0.005 & 0.006 \\
\hline Magnesium (ICP) & 0.004 & 0.0004 & 0.0004 \\
\hline Nickel (ICP) & 0.193 & 0.056 & 0.066 \\
\hline Silicon (ICP) & 0.287 & 0.014 & 0.010 \\
\hline Potassium (AA) & 0.035 & 0.020 & 0.020 \\
\hline Chromium (ICP) & 0.009 & 0.004 & 0.004 \\
\hline Zirconium (ICP) & 0.005 & 0.003 & 0.003 \\
\hline Titanium (ICP) & 0.004 & 0.002 & 0.002 \\
\hline Lead (ICP) & 0.14 & 0.061 & 0.07 \\
\hline Phosphorous (ICP) & 3.02 & 2.19 & 2.07 \\
\hline Phosphorous (IC) & 2.06 & 1.64 & 1.25 \\
\hline Nitrate (IC) & 59.13 & 76.32 & 75.95 \\
\hline Chloride (ISE) & 0.22 & 0.22 & 0.30 \\
\hline Sulfate (IC) & 0.21 & 0.21 & 0.72 \\
\hline Carbonate (titration) & 5.37 & 3.24 & 3.36 \\
\hline \multicolumn{4}{|l|}{ PROPERTIES } \\
\hline $\mathrm{pH}$ & 12.25 & 11.92 & 11.90 \\
\hline Sp Gravity $(\mathrm{g} / \mathrm{mL})$ & 1.08 & 1.09 & 1.12 \\
\hline$\%$ Solids & 10.35 & 10.22 & 11.05 \\
\hline \multicolumn{4}{|c|}{ CATION/ANION MASS BALANCE (moles/L) } \\
\hline$\sum \mathrm{Na}^{+}$ & 1.6 & 1.56 & 1.50 \\
\hline$\sum \mathrm{NO}_{3}=\mathrm{PO}_{4}^{-3}, \mathrm{AlO}_{2}^{-}$ & 1.37 & 1.56 & 1.55 \\
\hline
\end{tabular}


All wt $\%$ sludge solids were measured at $105^{\circ} \mathrm{C}$. All the sludge samples for analysis were dried at $300^{\circ} \mathrm{C}$ prior to dissolution. Sodium was analyzed by AA in all the $\mathrm{HCl} / \mathrm{HF}$ dissolutions and by ICP only in the $\mathrm{HCl} / \mathrm{HF}$ dissolutions performed after November 1988. The agreement between the various analyses for $\mathrm{Na}$ is excellent (Table $\mathrm{V}$ and Appendix I). Nickel was determined by both ICP and AA in all analyses after November 1988. Nickel by ICP is difficult due to interferences in the presence of uranium and AA is the preferred technique for analysis of $\mathrm{Ni}$ in the presence of uranium. To ensure that Ni determined by AA did not exhibit an enhancement in the presence of uranium (Table $\mathrm{V}$ and Appendix I), the uranium was precipitated out of one series of samples and the Ni analyses repeated. The Ni analyses determined by AA in the presence and absence of uranium were the same. Zinc and lead analyses by ICP can also be affected by the presence of uranium but no alternate technique is available for their determination.

Silicon was analyzed by ICP and by AA in all the analyses. In the March 1988 analyses the silicon concentration had been measured from the $\mathrm{HCl} / \mathrm{HF}$ dissolution. This number was biased higher than the ICP analyses for $\mathrm{Si}$ or the AA analyses for $\mathrm{Si}$ from the $\mathrm{Na}_{2} \mathrm{O}_{2}$ dissolution (analyses after November, 1988). This bias was attributed to the HF dissolving Si from the glass bead in the nebulizer of the AA. The results for the average silicon concentration determined by AA is therefore, only the average of the duplicate November analyses. Correspondingly, the AA results for $\mathrm{Si}$ in Appendix I are shown as italics and are not included in the average dry wt\% sludge analyses. Although ICP is the preferred technique for analysis of $\mathrm{Si}$, the ICP results for $\mathrm{Si}$ have higher standard deviations (Appendix I) than the AA results. The November 1988 AA results for $\mathrm{Si}$ are considered more accurate and used preferentially in this study.

Phosphorous was measured as $\mathrm{P}$ by ICP for sludges dissolved in $\mathrm{Na}_{2} \mathrm{O}_{2}$ with an $\mathrm{HCl}$ uptake. Phosphorous was measured as $\mathrm{PO}_{4}$ by ICP for sludges dissolved in $\mathrm{Na}_{2} \mathrm{O}_{2}$ with an $\mathrm{H}_{2} \mathrm{O}$ uptake. The observed differences in wt \% $\mathrm{P}$ shown in Table IV and Appendix I is attributed to differences in the acid soluble and water soluble concentrations of P. Note that the acid soluble P is always greater than the water soluble $\mathrm{P}$.

Tank 10 spent filter aid wt $\%$ solids were determined at $105^{\circ} \mathrm{C}$. Additional sample was dried at $300^{\circ} \mathrm{C}$ and the same dissolution procedures that were used on the dried sludge were used on the dried spent filter aid. Both the May 1992 and the July 1993 analyses are given in Table V. The details are given in Appendix I.

Uranium was analyzed by David-Gray titration for the sludges in Tanks 1-6 and 8. Uranium was analyzed by laser emission spectroscopy (Chemcheck) for Tanks 7 and 10 (Table V).

\section{Chemical Analysis of Sludge Crust}

The sludge crust from Tank 8 was analyzed in triplicate using the same procedures used for the sludge analyses from Tank 8. The results are reported in Table VI which shows that the crust is primarily $\mathrm{Al}$ enriched. Note that $\mathrm{U}$ was not analyzed by dissolution and ICP but U was identified as a component of the crust by the Energy Dispersive Spectroscopy (EDS) during the Scanning Electron Microscopy (SEM) analysis. The U was primarily attached to the sludge side of the crust. X-ray analysis indicated that $\mathrm{Al}(\mathrm{OH})_{3}$ was the primary crystalline phase and this is 
confirmed by the mass balance calculations in Table VI. The mass balance calculations do not sum to $100 \pm 5 \mathrm{wt} \%$ since all of the elements and the amount of moisture in the sample were not determined before chemical analysis.

\section{Chemical Analysis of Virgin Filter Aid}

The virgin filter aids used in wastewater treatment of the M-Area supernate were primarily perflo and diatomaceous earth. These two filter aids were chemically analyzed in March, 1988. Two other filter aids used subsequently, perlite 2000X and Renissance perlite (200 SP), were analyzed in February 1993. The diatomaceous earth and perflo filter aids were dried at $600^{\circ} \mathrm{C}$ overnight to determine their water content. The higher surface area perlites were more problematic, e.g. a constant weight for dissolution and subsequent chemical analysis was difficult to obtain. Hence, the perlites were fused at $1150^{\circ} \mathrm{C}$ for 4 hours before chemical analysis. Therefore, the perlite wt $\%$ moisture represents this higher temperature. The same dissolution procedures that were used on the M-Area sludge were used on the perflo, perlite and diatomaceous earth. Anions were not analyzed because these materials are oxide based and oxygen is the only anion present in these solids. A good analysis of an oxide bearing material should sum to $100 \pm 5 \mathrm{wt} \%$ on an oxide basis. $^{17}$

Table VII compares the analyses of perflo, diatomaceous earth, and perlite in terms of oxide wt $\%$. The elemental analyses and the conversions to oxide wt $\%$ are given in Appendix II. The oxide wt $\%$ sums in Table VII are within $100 \pm 5 \mathrm{wt} \%$ for all of these species. Since these species do not contain uranium and have not been in contact with M-Area wastes, the presence of $\mathrm{Zn}, \mathrm{Pb}$, and $\mathrm{Ni}$ is considered significant because some of the trace elements observed in the sludge analyses are originating from the processing additives. The diatomaceous earth was the least pure of all the filter aids used in processing.

\section{IDENTIFICATION OF PHASE CONSTITUENTS IN M-AREA SLUDGE AND CRUST}

X-ray diffraction was performed on sludge samples that had been dried at $90^{\circ} \mathrm{C}$ for 12 hours. The crystalline sludge species in the eight tanks included varying amounts of $\mathrm{NaNO}_{3}, \mathrm{Al}(\mathrm{OH})_{3}$ (both gibbsite and bayerite polymorphs), $\mathrm{Na}_{12} \mathrm{Al}_{12} \mathrm{Si}_{12} \mathrm{O}_{48} \bullet 27 \mathrm{H}_{2} \mathrm{O}$ or the Ca substituted form $\mathrm{Ca}_{6} \mathrm{Al}_{12} \mathrm{Si}_{12} \mathrm{O}_{48} \bullet 30 \mathrm{H}_{2} \mathrm{O}$ (Linde Zeolite-A), and poorly crystallized $\mathrm{Na}_{6} \mathrm{U}_{7} \mathrm{O}_{24}$ (partially converted in some tanks to $\mathrm{Na}_{2} \mathrm{U}_{2} \mathrm{O}_{7}$ ), and $\mathrm{AlPO}_{4}$. The Tank 10 spent filter aid was primarily amorphous but contained $\mathrm{NaNO}_{3}$, Zeolite-A, and a trace of $\mathrm{AlPO}_{4}$. The relative amounts of each phases in each tank was estimated by the relative peak heights of each species in the X-ray diffraction pattern. The results of the peak height analysis are given in 
Table VIII. Four designations are used, major for species present in the greatest quantity, trace for species present in the smallest quantities, present for species present in average concentration, and none for species not identified by XRD.

The identification of the sodium uranate species was difficult because it was poorly crystallized, e.g. the x-ray diffraction reflections for this phase were very broad instead of being sharply defined (see Figure 2). Positive identification of the poorly crystallized uranium phase was made by sequential heat treatment to higher and higher temperatures. After each heat treatment the dried sludge was analyzed by XRD again. Sludge from Tank 1 was heat treated at $300^{\circ} \mathrm{C}$ for 3 hours. The XRD indicated that the uranium phase was still poorly crystallized ( ), e.g. the uranate diffraction peaks are still broad and poorly defined. A subsequent heat treatment at $600^{\circ} \mathrm{C}$ overnight was performed which crystallized the $\mathrm{Na}_{6} \mathrm{U}_{7} \mathrm{O}_{24}$ to $\mathrm{Na}_{2} \mathrm{U}_{2} \mathrm{O}_{7}($ ). This transformation has been reported previously in the literature ${ }^{18}$ and was used to confirm the presence of the $\mathrm{Na}_{2} \mathrm{U}_{2} \mathrm{O}_{7}$ precursor phase, $\mathrm{Na}_{6} \mathrm{U}_{7} \mathrm{O}_{24}$. Similar results were obtained on Tank 7 samples heat treated to $600^{\circ} \mathrm{C}$ overnight. Note that the $\mathrm{NaNO}_{3}$ "disappears" from the higher temperature spectra shown in Figure 3 as the nitrate in the $\mathrm{NaNO}_{3}$ vaporizes at these temperatures. 
Table V. Summary of M-Area Sludge Analyses and Mass Balance Calculations

\begin{tabular}{|c|c|c|c|c|c|}
\hline $\begin{array}{l}\text { Element } \\
(\text { dry wt } \%)\end{array}$ & $\begin{array}{c}\text { Tank } 1 \\
(11 / 88)\end{array}$ & $\begin{array}{c}\text { Tank } 2 \\
(11 / 88)\end{array}$ & $\begin{array}{c}\text { Tank } 3 \\
(11 / 88)\end{array}$ & $\begin{array}{c}\text { Tank } 4 \\
(11 / 88)\end{array}$ & $\begin{array}{c}\text { Tank } 5 \\
(11 / 88)\end{array}$ \\
\hline \multicolumn{6}{|c|}{ CATIONS AND ANIONS } \\
\hline $\mathrm{Al}(\mathrm{ICP})$ & 11.145 & 7.130 & 6.383 & 3.043 & 9.778 \\
\hline $\mathrm{Ca}(\mathrm{ICP})$ & 0.325 & 0.310 & 0.304 & 0.205 & 0.327 \\
\hline $\mathrm{Fe}(\mathrm{ICP})$ & 0.495 & 0.260 & 0.655 & 0.215 & 0.495 \\
\hline $\mathrm{Mg}$ (ICP) & 0.154 & 0.076 & 0.069 & 0.070 & 0.137 \\
\hline $\mathrm{Mn}$ (ICP) & 0.539 & 1.315 & 1.025 & 0.734 & 0.392 \\
\hline $\mathrm{Na}$ (ICP) & 8.830 & 12.430 & 15.425 & 21.555 & 10.515 \\
\hline $\mathrm{Na}$ (AA) & 8.960 & 14.363 & 16.713 & 25.435 & 10.718 \\
\hline $\mathrm{Li}$ (ICP) & $<0.002$ & $<0.002$ & $<0.002$ & $<0.002$ & $<0.002$ \\
\hline $\mathrm{Ni}$ (ICP & 0.695 & 0.390 & 0.275 & 0.055 & 0.555 \\
\hline $\mathrm{Ni}$ (AA) & 0.876 & 0.556 & 0.385 & 0.082 & 0.758 \\
\hline $\mathrm{Si}$ (ICP) & 9.613 & 2.408 & 3.675 & 1.631 & 10.790 \\
\hline $\mathrm{Si}\left(\mathrm{AA}^{*}\right)$ & 16.140 & 3.140 & 4.105 & 3.323 & 14.030 \\
\hline $\mathrm{Cr}$ (ICP) & 0.015 & 0.013 & 0.010 & 0.015 & 0.015 \\
\hline B (ICP) & 0.060 & 0.075 & 0.025 & 0.015 & 0.015 \\
\hline$U(D-G)$ & 5.246 & 4.786 & 3.229 & 1.281 & 3.858 \\
\hline $\mathrm{Sr}$ (ICP) & 0.004 & 0.004 & 0.005 & 0.002 & 0.003 \\
\hline $\mathrm{Zr}$ (ICP) & 0.032 & 0.010 & 0.010 & 0.080 & 0.010 \\
\hline Ti (ICP) & 0.040 & 0.014 & 0.015 & 0.017 & 0.033 \\
\hline $\mathrm{K}(\mathrm{AA} *)$ & 0.122 & 0.033 & 0.054 & 0.021 & 0.104 \\
\hline $\mathrm{P}(\mathrm{ICP}) * * *$ & 1.548 & 1.465 & 1.953 & 1.298 & 1.270 \\
\hline $\mathrm{P}(\text { Calc IC })^{* *}$ & 0.774 & 0.975 & 1.291 & 0.376 & $<0.848$ \\
\hline $\mathrm{Ba}(\mathrm{ICP})$ & 0.008 & 0.017 & 0.030 & 0.032 & 0.016 \\
\hline $\mathrm{Pb}$ (ICP) & 0.161 & 0.213 & 0.157 & 0.136 & 0.124 \\
\hline Mo (ICP) & 0.011 & 0.010 & 0.010 & 0.010 & 0.010 \\
\hline $\mathrm{Zn}$ (ICP) & 0.960 & 2.155 & 1.720 & 1.294 & 0.945 \\
\hline $\mathrm{Cu}$ (ICP) & 0.018 & 0.016 & 0.014 & 0.020 & 0.009 \\
\hline F (ISE) & $<0.02$ & $<0.265$ & $<0.02$ & $<0.02$ & $<0.02$ \\
\hline $\mathrm{Cl}$ (ISE) & 0.113 & 0.189 & 0.142 & 0.220 & 0.843 \\
\hline $\mathrm{SO}_{4}(\mathrm{IC})$ & $<0.50$ & $<0.50$ & $<0.50$ & $<0.50$ & $<1.31$ \\
\hline $\mathrm{NO}_{3}(\mathrm{IC})$ & 14.275 & 34.660 & 50.580 & 59.500 & 12.000 \\
\hline $\mathrm{PO}_{4}(\mathrm{IC})^{* *}$ & 2.989 & 2.375 & 3.960 & 1.152 & $<2.6$ \\
\hline \multicolumn{6}{|c|}{ PROPERTIES } \\
\hline $\begin{array}{l}\text { \% SOLIDS } \\
\left(105^{\circ} \mathrm{C}\right)\end{array}$ & 35.37 & 38.98 & 9.24 & 22.34 & 32.49 \\
\hline \multicolumn{6}{|c|}{ MOLAR MASS BALANCE } \\
\hline $\mathrm{Al}(\mathrm{OH})_{3}$ & 27.06 & 15.72 & 12.35 & 4.73 & 23.80 \\
\hline $\mathrm{NaNO}_{3}$ & 19.57 & 47.51 & 69.33 & 81.56 & 16.45 \\
\hline Filter Aid & 36.31 & 5.79 & 8.52 & 7.03 & 20.04 \\
\hline $\mathrm{Na}_{6} \mathrm{U}_{7} \mathrm{O}_{24}$ & 6.89 & 6.29 & 4.24 & 1.68 & 5.07 \\
\hline Ca Zeolite-A & 2.99 & 2.85 & 2.79 & 1.88 & 3.00 \\
\hline $\mathrm{AlPO}_{4}$ & 4.75 & 4.49 & 5.99 & 3.98 & 3.89 \\
\hline SUM & 97.55 & 82.64 & 103.22 & 101.86 & 81.25 \\
\hline
\end{tabular}

*AA Silicon from $\mathrm{Na}_{2} \mathrm{O}_{2}$ dissolution; all anions from $\mathrm{Na}_{2} \mathrm{O}_{2}$ fusion with $\mathrm{H}_{2} \mathrm{O}$ uptake (see text)

**water soluble phosphate only, *** acid soluble phosphate, N/A = Not Analyzed 
Table V. Summary of M-Area Sludge Analyses and Mass Balance Calculations

\begin{tabular}{|c|c|c|c|c|c|}
\hline $\begin{array}{l}\text { Element } \\
\text { (dry wt\%) }\end{array}$ & $\begin{array}{l}\text { Tank } 6 \\
(11 / 88)\end{array}$ & $\begin{array}{l}\text { Tank } 7 \\
(5 / 92)\end{array}$ & $\begin{array}{c}\text { Tank } 8 \\
\text { Average } \\
(11 / 88)\end{array}$ & $\begin{array}{c}\text { Tank } 10 \\
(5 / 92)\end{array}$ & $\begin{array}{c}\text { Tank } 10 \\
(7 / 93)\end{array}$ \\
\hline \multicolumn{6}{|c|}{ CATIONS AND ANIONS } \\
\hline $\mathrm{Al}(\mathrm{ICP})$ & 10.013 & 6.392 & 10.734 & 8.896 & 9.642 \\
\hline $\mathrm{Ca}(\mathrm{ICP})$ & 0.497 & 0.420 & 0.307 & 0.351 & 0.425 \\
\hline $\mathrm{Fe}(\mathrm{ICP})$ & 0.740 & 0.529 & 0.402 & 0.870 & 1.046 \\
\hline $\mathrm{Mg}(\mathrm{ICP})$ & 0.188 & 0.125 & 0.122 & 0.122 & 0.122 \\
\hline $\mathrm{Mn}$ (ICP) & 1.535 & 0.005 & 0.422 & 0.035 & 0.049 \\
\hline $\mathrm{Na}$ (ICP) & 9.670 & 12.292 & 7.010 & 7.196 & 5.132 \\
\hline $\mathrm{Na}(\mathrm{AA})$ & 10.228 & 13.430 & 7.056 & 7.433 & 5.233 \\
\hline $\mathrm{Li}(\mathrm{ICP})$ & $<0.002$ & $<0.001$ & $<0.002$ & $<0.001$ & $<0.001$ \\
\hline Ni (ICP & 0.425 & 1.871 & 0.728 & 0.064 & 0.081 \\
\hline Ni (AA) & 0.601 & 1.985 & 0.990 & $<0.06$ & $<0.06$ \\
\hline Si (ICP) & 12.310 & 15.869 & 11.301 & 24.785 & 25.144 \\
\hline $\mathrm{Si}\left(\mathrm{AA}^{*}\right)$ & 18.000 & 17.985 & 14.715 & 27.445 & 24.845 \\
\hline $\mathrm{Cr}$ (ICP) & 0.020 & $<0.004$ & 0.017 & $<0.004$ & $<0.004$ \\
\hline $\mathrm{B}$ (ICP) & 0.010 & 0.037 & 0.010 & $<0.004$ & $<0.004$ \\
\hline $\begin{array}{l}\text { U (D-G, } \\
\text { chemcheck } \dagger \text { ) }\end{array}$ & 4.080 & $3.005 \dagger$ & 5.133 & $0.045 \dagger$ & $0.222 \dagger$ \\
\hline $\mathrm{Sr}$ (ICP) & 0.006 & N/A & 0.006 & N/A & 0.002 \\
\hline $\mathrm{Zr}$ (ICP) & 0.010 & $<0.002$ & 0.010 & $<0.002$ & $<0.002$ \\
\hline $\mathrm{Ti}$ (ICP) & 0.038 & 0.024 & 0.029 & 0.027 & 0.062 \\
\hline $\mathrm{K}\left(\mathrm{AA}^{*}\right)$ & 0.107 & 0.580 & 0.121 & 2.605 & 2.053 \\
\hline $\mathrm{P}(\mathrm{ICP}) * * *$ & 1.135 & 1.137 & 1.896 & 1.031 & 0.959 \\
\hline $\mathrm{P}($ Calc IC $) * *$ & 0.244 & 1.963 & 0.973 & 1.035 & 0.997 \\
\hline $\mathrm{Ba}(\mathrm{ICP})$ & 0.047 & N/A & 0.053 & N/A & 0.016 \\
\hline $\mathrm{Pb}$ (ICP) & 0.245 & 0.156 & 0.137 & 0.035 & 0.032 \\
\hline Mo (ICP) & 0.015 & $<0.004$ & 0.009 & $<0.004$ & 0.005 \\
\hline $\mathrm{Zn}$ (ICP) & 2.875 & 0.176 & 0.794 & 0.172 & 0.464 \\
\hline $\mathrm{Cu}(\mathrm{ICP})$ & 0.026 & 0.086 & 0.022 & 0.003 & 0.065 \\
\hline F (ISE) & $<0.02$ & 0.050 & N/A & 0.060 & 1.189 \\
\hline $\mathrm{Cl}$ (ISE) & 0.060 & 0.675 & 0.059 & 0.310 & 0.134 \\
\hline $\mathrm{SO}_{4}(\mathrm{IC})$ & $<0.5$ & 0.237 & $<0.5$ & $<0.2$ & 0.332 \\
\hline $\mathrm{NO}_{3}(\mathrm{IC})$ & 12.870 & 15.135 & 16.376 & 7.935 & 6.202 \\
\hline $\mathrm{PO}_{4}(\mathrm{IC})^{* *}$ & 0.749 & 6.019 & 2.984 & 3.175 & 3.057 \\
\hline \multicolumn{6}{|c|}{ PROPERTIES } \\
\hline $\begin{array}{l}\% \text { SOLIDS } \\
\left(105^{\circ} \mathrm{C}\right)\end{array}$ & 37.12 & 30.85 & 38.23 & 17.56 & 19.97 \\
\hline \multicolumn{6}{|c|}{ MOLAR MASS BALANCE } \\
\hline $\mathrm{Al}(\mathrm{OH})_{3}$ & 24.15 & 13.98 & 25.06 & 23.12 & 23.81 \\
\hline $\mathrm{NaNO}_{3}$ & 17.64 & 20.75 & 22.45 & 27.48 & 8.50 \\
\hline Filter Aid & 40.05 & 40.27 & 33.07 & 52.95 & 53.62 \\
\hline $\mathrm{Na}_{6} \mathrm{U}_{7} \mathrm{O}_{24}$ & 5.36 & 3.95 & 6.75 & 0.06 & 0.29 \\
\hline Ca Zeolite-A & 4.57 & 3.86 & 2.82 & 1.30 & 3.91 \\
\hline $\mathrm{AlPO}_{4}$ & 3.48 & 3.49 & 5.82 & 3.16 & 2.94 \\
\hline SUM & 95.26 & 86.29 & 95.96 & 108.065 & 95.58 \\
\hline
\end{tabular}


Table VI. Summary of M-Area Crust Analyses from Tank 8

\begin{tabular}{|c|c|c|c|c|}
\hline $\begin{array}{l}\text { Element } \\
\text { (dry wt\%) }\end{array}$ & $\begin{array}{c}\text { Replicate } \\
\# 1 \\
\text { ADS\#200027146 }\end{array}$ & $\begin{array}{c}\text { Replicate } \\
\# 2 \\
\text { ADS\#200027147 }\end{array}$ & $\begin{array}{c}\text { Replicate } \\
\# 3 \\
\text { ADS\#200027148 }\end{array}$ & Average \\
\hline \multicolumn{5}{|c|}{ CATIONS AND ANIONS } \\
\hline $\mathrm{Al}(\mathrm{ICP})$ & 27.553 & 23.568 & 24.330 & 25.150 \\
\hline $\mathrm{Ca}(\mathrm{ICP})$ & BDL & 0.015 & BDL & 0.005 \\
\hline $\mathrm{Fe}(\mathrm{ICP})$ & 0.223 & 0.048 & 0.056 & 0.109 \\
\hline $\mathrm{Mg}(\mathrm{ICP})$ & 0.006 & 0.007 & 0.011 & 0.008 \\
\hline $\mathrm{Mn}$ (ICP) & 0.004 & BDL & 0.006 & 0.003 \\
\hline $\mathrm{Na}(\mathrm{ICP})$ & 1.490 & 1.640 & 1.200 & 1.443 \\
\hline $\mathrm{Na}$ (AA) & 1.340 & 1.060 & 1.310 & 1.237 \\
\hline $\mathrm{Li}(\mathrm{ICP})$ & 0.006 & BDL & BDL & 0.002 \\
\hline $\mathrm{Ni}$ (ICP & 0.022 & 0.038 & 0.058 & 0.039 \\
\hline $\mathrm{Ni}$ (AA) & 0.071 & 0.106 & 0.124 & 0.100 \\
\hline Si (ICP) & 0.858 & 0.969 & 1.268 & 1.032 \\
\hline $\mathrm{Si}\left(\mathrm{AA}^{*}\right)$ & 1.610 & 1.400 & 1.560 & 1.523 \\
\hline $\mathrm{Cr}$ (ICP) & BDL & BDL & BDL & BDL \\
\hline $\mathrm{B}$ (ICP) & 0.086 & 0.042 & 0.040 & 0.056 \\
\hline $\mathrm{U}(\mathrm{D}-\mathrm{G})$ & N/A & N/A & N/A & N/A \\
\hline $\mathrm{Sr}$ (ICP) & BDL & BDL & BDL & BDL \\
\hline $\mathrm{Zr}$ (ICP) & BDL & BDL & BDL & $\mathrm{BDL}$ \\
\hline $\mathrm{Ti}(\mathrm{ICP})$ & BDL & BDL & BDL & BDL \\
\hline $\mathrm{K}\left(\mathrm{AA}^{*}\right)$ & 0.004 & $<0.001$ & 0.014 & 0.009 \\
\hline $\mathrm{P}(\mathrm{ICP}) * * *$ & 0.184 & 0.160 & 0.234 & 0.193 \\
\hline $\mathrm{P}(\text { Calc IC })^{* *}$ & 0.774 & 1.002 & 1.171 & 0.982 \\
\hline $\mathrm{Ba}(\mathrm{ICP})$ & BDL & BDL & BDL & BDL \\
\hline $\mathrm{Pb}(\mathrm{ICP})$ & BDL & BDL & BDL & BDL \\
\hline Mo (ICP) & 0.009 & BDL & 0.007 & BDL \\
\hline $\mathrm{Zn}(\mathrm{ICP})$ & 0.145 & 0.149 & 0.139 & 0.144 \\
\hline $\mathrm{Cu}(\mathrm{ICP})$ & BDL & BDL & 0.004 & BDL \\
\hline F (ISE) & 0.116 & 0.495 & 0.105 & 0.239 \\
\hline $\mathrm{Cl}$ (ISE) & 1.520 & 0.977 & 0.413 & 0.970 \\
\hline $\mathrm{SO}_{4}(\mathrm{IC})$ & N/A & N/A & N/A & N/A \\
\hline $\mathrm{NO}_{3}(\mathrm{IC})$ & 3.716 & 6.062 & 8.496 & 6.091 \\
\hline $\mathrm{PO}_{4}(\mathrm{IC}) * *$ & 2.374 & 3.073 & 3.590 & 3.012 \\
\hline \multicolumn{5}{|c|}{ PROPERTIES } \\
\hline $\begin{array}{l}\% \text { SOLIDS } \\
\left(105^{\circ} \mathrm{C}\right)\end{array}$ & N/A & N/A & N/A & N/A \\
\hline \multicolumn{5}{|c|}{ MOLAR MASS BALANCE } \\
\hline $\mathrm{Al}(\mathrm{OH})_{3}$ & 79.19 & 67.67 & 69.75 & 72.21 \\
\hline $\mathrm{NaNO}_{3}$ & 5.09 & 8.31 & 11.65 & 8.35 \\
\hline Filter Aid & 3.73 & 3.24 & 3.61 & 3.53 \\
\hline $\mathrm{Na}_{6} \mathrm{U}_{7} \mathrm{O}_{24}$ & N/A & N/A & N/A & N/A \\
\hline Ca-zeolite & BDL & 0.14 & BDL & 0.05 \\
\hline $\mathrm{AlPO}_{4}$ & 0.56 & 0.49 & 0.72 & 0.59 \\
\hline SUM & 88.578 & 79.85 & 85.73 & 84.72 \\
\hline
\end{tabular}

N/A = Not Analyzed; BDL = Below Detection Limit 
Table VII. Summary of M-Area Filter Aid Analyses

\begin{tabular}{|c|c|c|c|c|}
\hline $\begin{array}{c}\text { Oxide } \\
(\text { dry wt \%) }\end{array}$ & $\begin{array}{l}\text { Diatomaceous } \\
\text { Earth (DE) } \ddagger\end{array}$ & $\begin{array}{l}\text { Super-Cel } \\
\text { Perflo } \neq\end{array}$ & Perlite* 2000X & Perlite* 200SP \\
\hline $\mathrm{Al}_{2} \mathrm{O}_{3}$ & 16.08 & 12.36 & 12.48 & 12.93 \\
\hline $\mathrm{CaO}$ & 0.91 & 0.92 & 0.70 & 0.61 \\
\hline $\mathrm{Fe}_{2} \mathrm{O}_{3}$ & 0.92 & 1.67 & 0.88 & 1.02 \\
\hline $\mathrm{MgO}$ & 0.13 & 0.12 & 0.11 & 0.30 \\
\hline $\mathrm{MnO}_{2}$ & 0.90 & 0.59 & 0.10 & 0.08 \\
\hline $\mathrm{Na}_{2} \mathrm{O}$ & 3.28 & 3.55 & 4.48 & 3.42 \\
\hline $\mathrm{NiO}$ & 0.31 & $\mathrm{BDL}$ & $\mathrm{BDL}$ & 0.08 \\
\hline $\mathrm{SiO}_{2}$ & 67.32 & 72.95 & 74.75 & 75.43 \\
\hline $\mathrm{B}_{2} \mathrm{O}_{3}$ & $\mathrm{BDL}$ & $\mathrm{BDL}$ & BDL & BDL \\
\hline $\mathrm{ZrO}_{2}$ & 0.01 & 0.01 & 0.01 & 0.01 \\
\hline $\mathrm{TiO}_{2}$ & 0.07 & 0.07 & 0.06 & 0.10 \\
\hline $\mathrm{K}_{2} \mathrm{O}$ & 4.46 & 4.82 & 5.42 & 5.05 \\
\hline $\mathrm{P}_{2} \mathrm{O}_{5}$ & 0.44 & 0.09 & 0.03 & 0.03 \\
\hline $\mathrm{BaO}$ & 0.03 & 0.04 & 0.04 & 0.02 \\
\hline $\mathrm{PbO}$ & 0.19 & 0.10 & BDL & BDL \\
\hline $\mathrm{ZnO}$ & 1.12 & 0.67 & 0.19 & 0.19 \\
\hline $\mathrm{CuO}$ & 0.03 & 0.03 & BDL & BDL \\
\hline SUM & 96.20 & 97.99 & 99.24 & 99.28 \\
\hline \multicolumn{5}{|c|}{ MOISTURE CONTENT BEFORE DRYING/FUSING } \\
\hline $\mathrm{H}_{2} \mathrm{O}$ & 7.37 & 0.20 & 0.04 & 0.13 \\
\hline
\end{tabular}

*The high surface area of these filter aids made it difficult to get an accurate weight for the dissolution and subsequent chemical analysis. In these cases the filter aid was fused at $1150^{\circ} \mathrm{C}$ for 4 hours, cooled, broken out of the crucible it was fused in, and then weighed for dissolution and analysis

$\mathrm{BDL}=$ Below Detection Limit

$\ddagger$ Dried at $600^{\circ} \mathrm{C}$ 


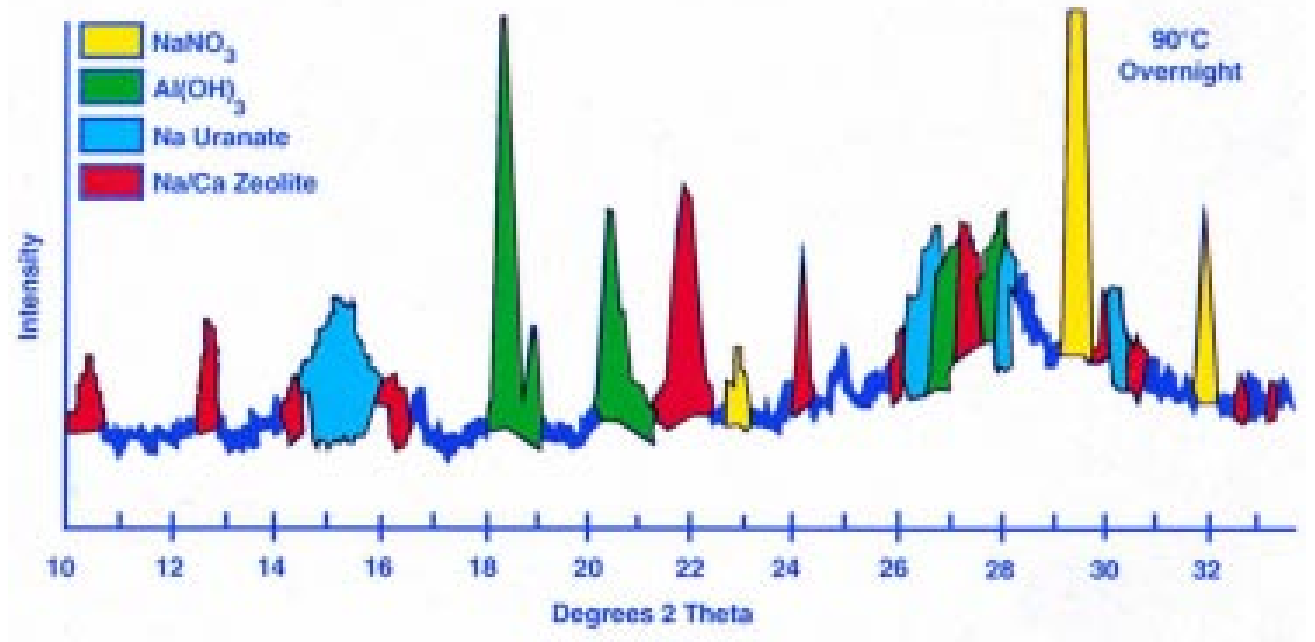

Figure 2. X-ray diffraction pattern of the M-Area sludge dried at $90^{\circ}$ overnight. Note how broad the $x$-ray diffraction peaks are for the sodium uranate phase compared to the other crystalline species present.
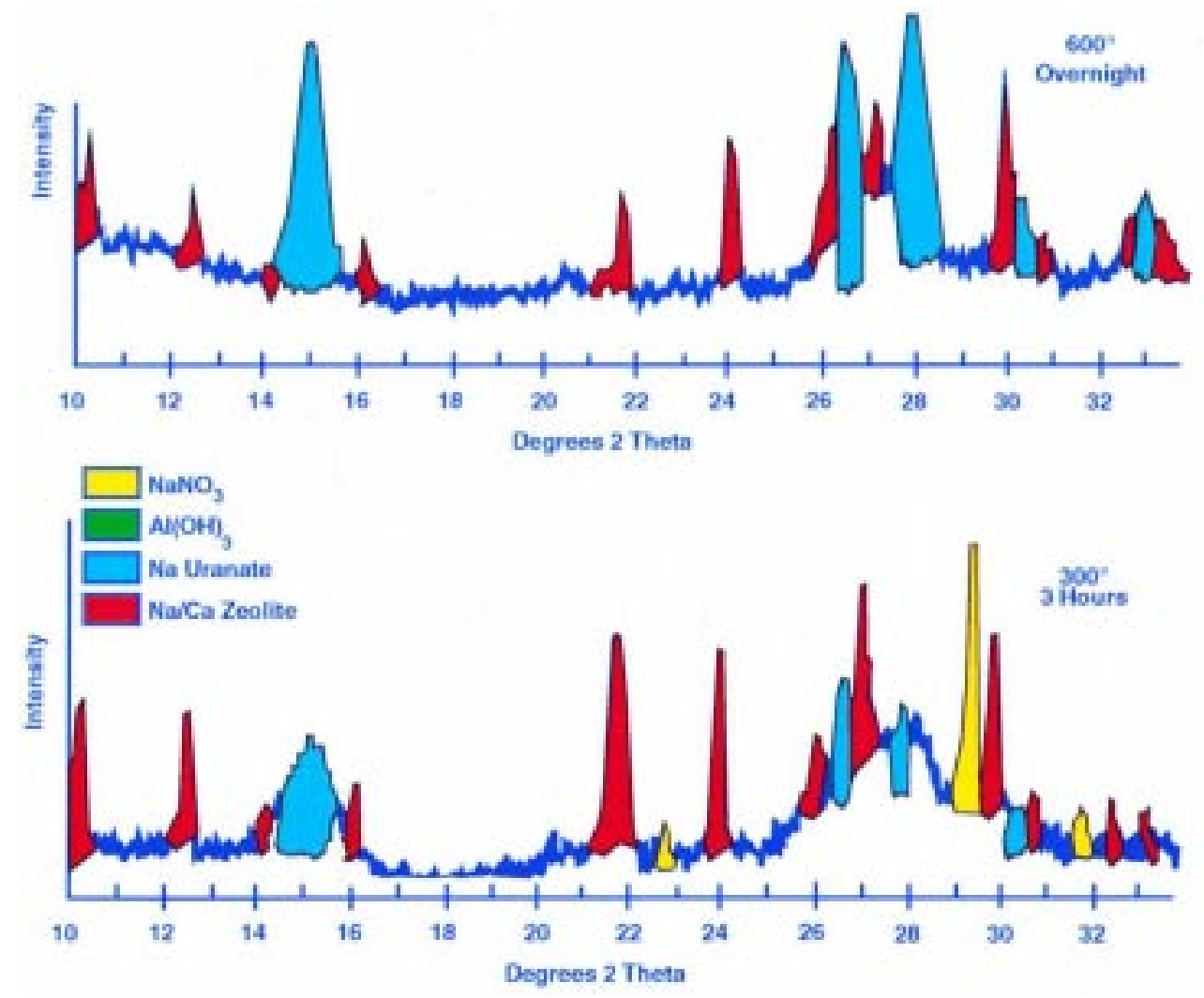

Figure 3. X-ray diffraction pattern of the M-Area sludge heat treated at $300^{\circ} \mathrm{C}$ and $600^{\circ} \mathrm{C}$. 
Table VIII. X-Ray Diffraction Phase Identification and Relative Concentrations of the Species in M-Area Sludge and Spent Filter Aid

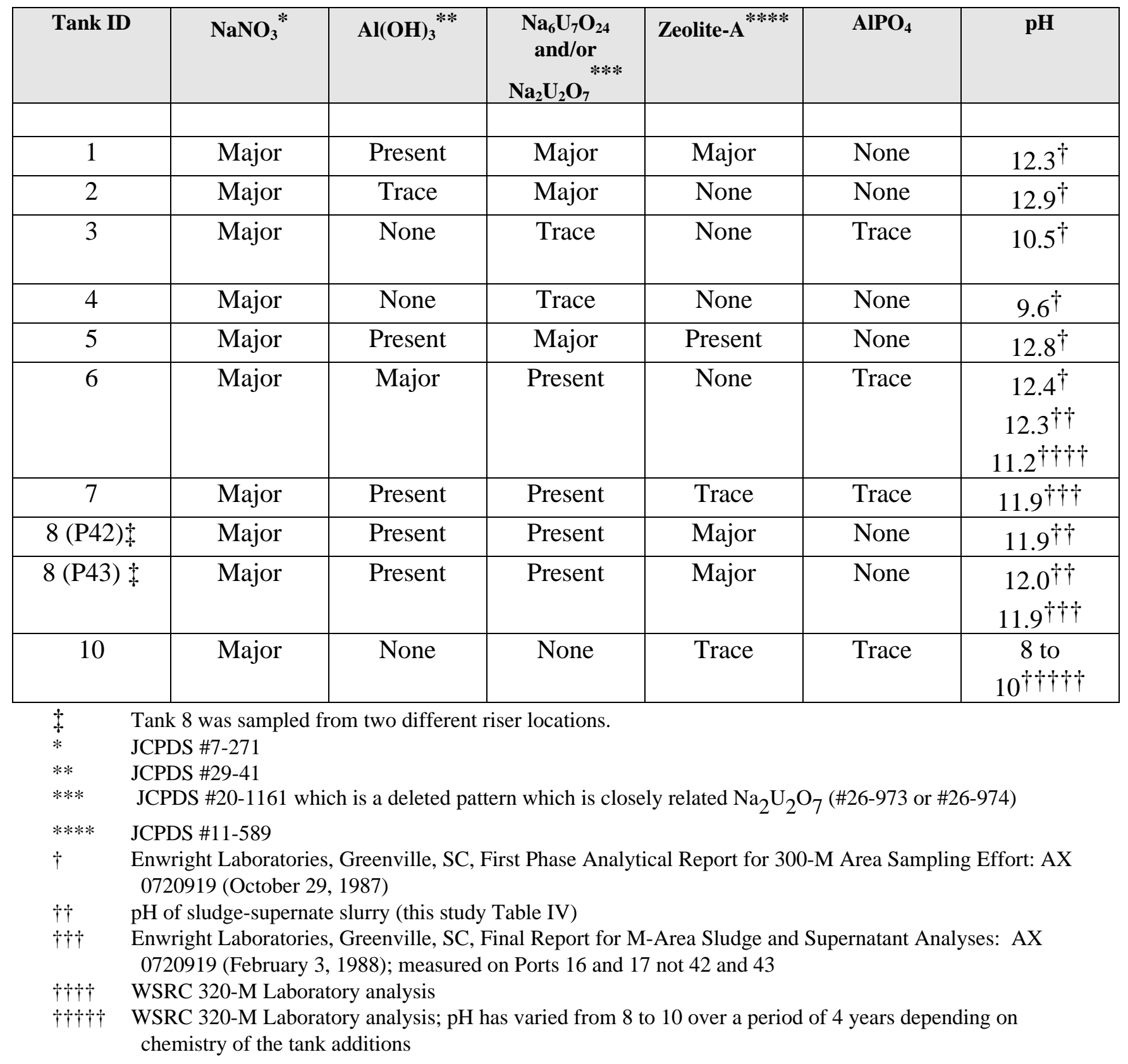

The $\mathrm{Na}_{6} \mathrm{U}_{7} \mathrm{O}_{24}$ phase has previously reported to form when uranium is precipitated from uranyl nitrate solution when excess sodium hydroxide is added. ${ }^{19}$ It is the primary uranate species which is stable in the presence of excess alkali. ${ }^{19}$ Since the M-Area waste tanks normally stabilize at a $\mathrm{pH}$ of 11-12 (due to excess $\mathrm{NaOH}$ used during the aluminum dissolution process), the identification of this sodium uranate is consistent with the chemical environment of the IT/SF tanks, e.g. the tanks with the lowest $\mathrm{pH}$ (Tanks 3 and 4) have only trace amounts of $\mathrm{Na}_{6} \mathrm{U}_{7} \mathrm{O}_{24}$ in the $\mathrm{x}$-ray spectra (Table VIII). Conversely, the tanks with the highest $\mathrm{U}$ concentrations and 
highest $\mathrm{pH}$ (Tanks 1,5,8) have the highest concentrations of $\mathrm{Na}_{6} \mathrm{U}_{7} \mathrm{O}_{24}$.

In addition, the tanks (Tanks 3 and 4 ) with the lowest $\mathrm{Al}$ concentration have no $\mathrm{Al}(\mathrm{OH})_{3}$ in the XRD spectra. Conversely, the tanks (Tanks 1, 5, 8) with the highest Al contain the most $\mathrm{Al}(\mathrm{OH})_{3}$ in the XRD spectra. The tanks with the highest $\mathrm{pH}$ values which also have significant concentrations of $\mathrm{Al}(\mathrm{OH})_{3}$ (Tanks 1 and 5) are the tanks containing the most Zeolite-A. The quantitative phase analysis of the tanks is, therefore, consistent with the individual tank chemistries and environments (Table VIII).

The primary crystalline phase of the $\mathrm{M}$-Area crust was $\mathrm{NaNO}_{3}$ and $\mathrm{Al}(\mathrm{OH})_{3}$ (primarily the gibbsite polymorph) with trace amounts of $\mathrm{Na}_{2} \mathrm{U}_{2} \mathrm{O}_{7}$ and Zeolite-A. This was confirmed by SEMEDS analysis which showed $\mathrm{Al}$ to be the major component of the crust, followed by $\mathrm{Si}, \mathrm{U}$ and $\mathrm{Na}$. This is also in agreement with the chemical analyses given in Table VI.

\section{IDENTIFICATION OF IN-TANK ZEOLITE FORMATION}

The zeolite identified in the M-Area sludge was identified as either a calcium or a sodium containing Zeolite-A with the nominal formulas $\mathrm{Ca}_{6} \mathrm{Al}_{12} \mathrm{Si}_{12} \mathrm{O}_{48} \cdot 30 \mathrm{H}_{2} \mathrm{O}$ and $\mathrm{Na}_{12} \mathrm{Al}_{12} \mathrm{Si}_{12} \mathrm{O}_{48}$ $-27 \mathrm{H}_{2} \mathrm{O}$. However, zeolite was not used in M-Area processing nor had any zeolite been added to the tanks. This finding indicated that the zeolite formed from reaction of various components in the tank. In order to confirm this hypothesis, samples of virgin perflo and diatomaceous earth were analyzed by x-ray diffraction and shown to be amorphous (see Figure 4). Samples of perflo and diatomaceous earth were treated with $6 \mathrm{M} \mathrm{NaOH}$ solution at room temperature for 29 hours. The solution $\mathrm{pH}$ was 13.73 . The solution was filtered off and the solids dried at $80^{\circ} \mathrm{C}$ for $\sim 17$ hours. The solids were still wet, and were dried for an additional 1.5 hours at $200^{\circ} \mathrm{C}$. The dried solids were identified by $\mathrm{x}$-ray analysis to be $\mathrm{Na}_{2} \mathrm{SiO}_{3}$ (JCPDS \#16-818) and $\mathrm{Na}_{3} \mathrm{Si}_{3} \mathrm{Al}_{3} \mathrm{O}_{12} \cdot \mathrm{NaCl}$ (sodalite - JCPDS \#20-495), a zeolite formed from Zeolite-A by substitution of $\mathrm{NaCl}$ or other sodium species such as $\mathrm{NaOH}$ into the Zeolite-A lattice structure. In order to ensure that crystallization of the sodalite was due to the treatment with $\mathrm{NaOH}$ and not the drying, untreated filter aids were dried at $200^{\circ} \mathrm{C}$ for 1.5 hours. The untreated filter aids remained $\mathrm{x}$-ray amorphous confirming that the Zeolite phases formed by reaction of the silica rich filter aids with $\mathrm{NaOH}$.

In tank formation of Zeolite-A by chemically catalyzed crystallization of perflo and diamateceous earth due to the high caustic content and the high $\mathrm{pH}$ of the $\mathrm{M}$-Area supernate is consistent with the known formation of zeolites. For example, Linde $\mathrm{B}_{1}$ zeolite is fabricated via a patented process which treats aluminosilicate gel ("Alfloc") in concentrated $\mathrm{NaOH}$ at temperatures of $60-110^{\circ} \mathrm{C}^{20}$

Additional evidence for in-tank, chemically catalyzed crystallization of Zeolite-A from the aluminosilicate rich portion of the sludge was achieved by dissolving M-Area sludge in $6 \mathrm{M}$ $\mathrm{HNO}_{3}$ and analyzing the undissolved residue. The acid resistant residue in the M-Area sludge is pure $\mathrm{SiO}_{2}$ (crystalline cristobolite and traces of quartz). Because cristobolite and quartz are crystalline species and acid resistant, they are the breakdown products of a crystalline silicate not of the amorphous perflo. This indicates that the cristobolite is the breakdown product of the Zeolite-A and not the original filter aid. 

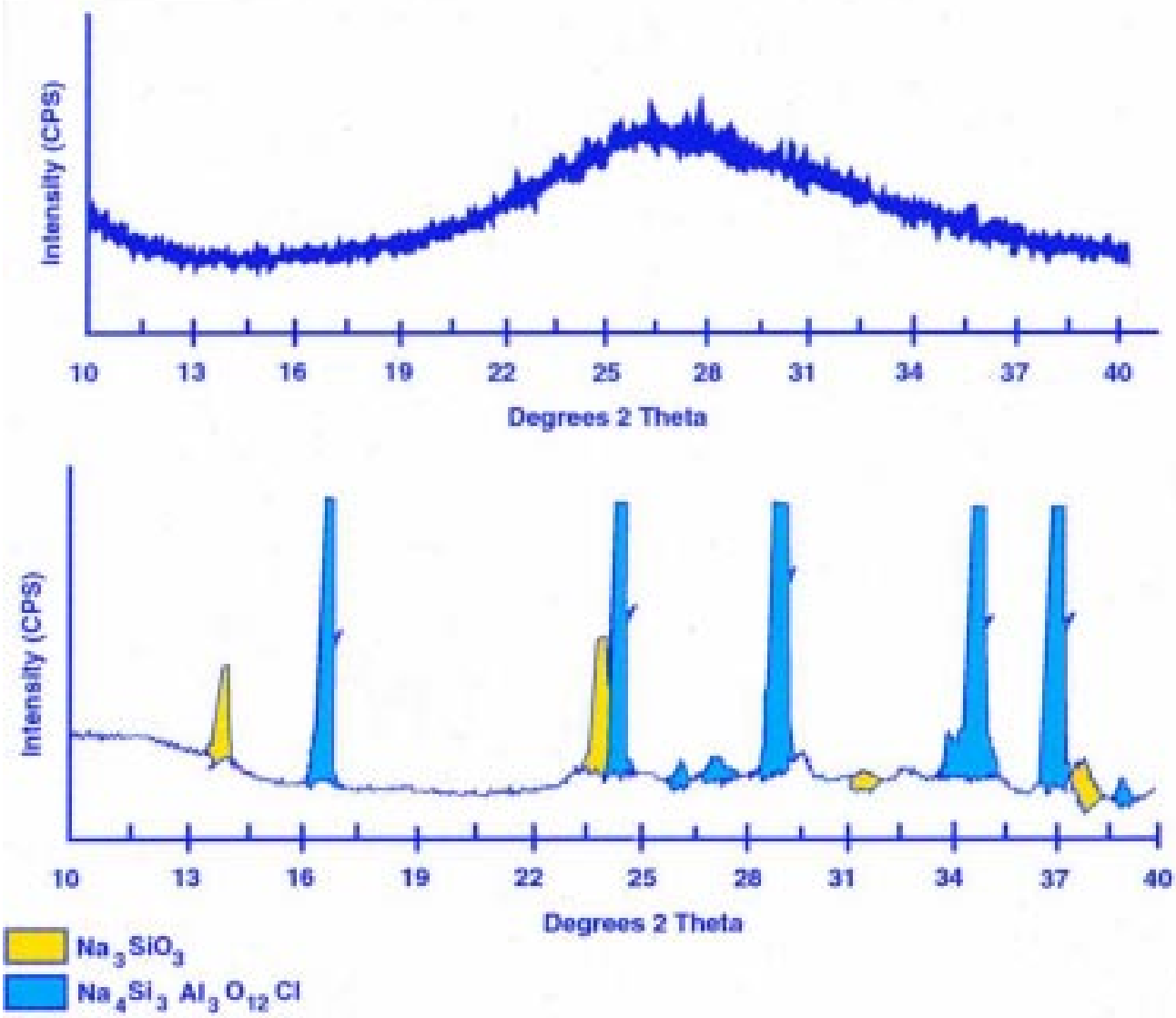

Figure 4. X-ray analysis of untreated (virgin) perflo and diatomaceous earth indicated that these materials were amorphous (top) while treatment with $6 \mathrm{M} \mathrm{NaOH}$ for 29 hours at room temperature crystallized $\mathrm{Na}_{2} \mathrm{SiO}_{3}$ and sodalite (a mineral related in structure to Zeolite-A). 


\section{MASS BALANCE CALCULATIONS}

The x-ray diffraction analysis indicated that the crystalline species present in the M-Area sludges are $\mathrm{NaNO}_{3}, \mathrm{Na}_{6} \mathrm{U}_{7} \mathrm{O}_{24}, \mathrm{Al}(\mathrm{OH})_{3}, \mathrm{AlPO}_{4}$, and Zeolite-A of the approximate formula $\mathrm{Ca}_{6} \mathrm{Al}_{12} \mathrm{Si}_{12} \mathrm{O}_{48} \cdot 30 \mathrm{H}_{2} \mathrm{O}$ (with a molecular weight of 2210 grams) or $\mathrm{Na}_{12} \mathrm{Al}_{12} \mathrm{Si}_{12} \mathrm{O}_{48} \cdot 27 \mathrm{H}_{2} \mathrm{O}$ (with a molecular weight of 2242 grams). The remainder of the sludge is amorphous perlite or perflo. A mass balance based on these 5 crystalline species and amorphous $\mathrm{SiO}_{2}$ was calculated from the element wt\% analyses given in Table V and Table VI for the M-Area sludges and crust, respectively.

Table IX shows a sample molar mass balance calculation for Tank-1 sludge. In the molar mass balance calculations all of the molar $\mathrm{NO}_{3}$ was assumed to form $\mathrm{NaNO}_{3}$. All of the molar $\mathrm{U}$ was assumed to form $\mathrm{Na}_{6} \mathrm{U}_{7} \mathrm{O}_{24}$. All of the molar Ca was assumed to form Ca rich Zeolite-A. All of the acid soluble molar $\mathrm{PO}_{4}$ determined by ICP was assumed to form $\mathrm{AlPO}_{4}$. The molar $\mathrm{Al}$ concentration minus the molar amount of $\mathrm{Al}$ assigned to $\mathrm{AlPO}_{4}$ minus the molar concentration of $\mathrm{Al}$ in the Zeolite-A was assumed to form $\mathrm{Al}(\mathrm{OH})_{3}$. All of the Si determined by AA minus the amount of Si consumed in the Zeolite-A phase, was assigned to the filter aid as described below.

The average molecular formulas for the filter aid species were determined from the normalized oxide mole\% analyses given in Appendix II. Based on the data in Appendix II the average molecular formulas for these filter aid species can be written as follows on an equal oxygen basis:

$$
\begin{gathered}
\text { perflo }=\mathrm{K}_{0.08} \mathrm{Na}_{0.08} \mathrm{Al}_{0.165} \mathrm{Si}_{0.83} \mathrm{O}_{2} \\
\text { diatomaceous earth }=\mathrm{K}_{0.08} \mathrm{Na}_{0.08} \mathrm{Al}_{0.23} \mathrm{Si}_{0.79} \mathrm{O}_{2} .
\end{gathered}
$$

For perflo the average molecular weight is 64.53 and for diatomaceous earth the average molecular weight is 65.45. Since the relative amounts of each filter aid used in any one M-Area tank is unknown, an average molecular weight of 65 grams was used to calculate the contribution of the filter aids to the mass balance.

The resulting mass balance results are summarized in Table V and Table VI and Appendix I. The mass balance sums calculated from the chemical analyses in Table V sum to be between 95105 mole\% indicating that most of the chemical analyses are accurate. Deviations from mass balance of $100 \pm 5$ mole\% appear to be due to incorrect speciation of Na. Excess Na over that assigned to $\mathrm{NaNO}_{3}$ and $\mathrm{Na}_{6} \mathrm{U}_{7} \mathrm{O}_{24}$ was calculated as moles/100grams (Appendix I). This probably should have been assigned to the Zeolite-A phase since this is a mixed Na-Ca Zeolite-A but the mass balance calculations assumed a pure $\mathrm{Ca}$ bearing Zeolite-A. The Na may also be partially tied up in minor phases such as $\mathrm{NaCl}$ and sodium aluminate phases which did not show up during x-ray diffraction analysis due to their low volume fraction. Interestingly, the tanks with excess $\mathrm{Na}$ in the mass balance (Tanks 1,5 and 6) have relatively high $\mathrm{pH}$ values, while the tanks such as 3 and 4 which do not have excess $\mathrm{Na}$ have lower $\mathrm{pH}$ values. 
Table IX. Example of Mass Balance Calculation for M-Area Sludge (Tank 1)

Row Column A

$\underline{\text { ID } \quad \text { Element }(w t \%)}$

$\begin{array}{cll}3 & \mathrm{Al} \text { (ICP) } & 11.145 \\ 4 & \mathrm{Ca} \text { (ICP) } & \\ 5 & \mathrm{Fe} \text { (ICP) } & 0.495 \\ 6 & \mathrm{Mg} \text { (ICP) } & 0.154 \\ 7 & \mathrm{Mn} \text { (ICP) } & 0.539 \\ 8 & \mathrm{Na} \text { (ICP) } & 8.83 \\ 9 & \mathrm{Na} \text { (AA) } & 8.96\end{array}$

$10 \quad \mathrm{Li}(\mathrm{ICP}) \quad<0.002$

$11 \quad \mathrm{Ni}$ (ICP) 0.695

$12 \quad \mathrm{Ni}(\mathrm{AA}) \quad 0.876$

$13 \quad \mathrm{Si}(\mathrm{ICP}) \quad 9.613$

$14 \quad \mathrm{Si}\left(\mathrm{AA}^{*}\right) \quad 16.14$

$15 \quad \mathrm{Cr}(\mathrm{ICP}) \quad 0.015$

16 B (ICP) 0.06

17 U (D-G) $\quad 5.246$

$18 \quad \mathrm{Sr}(\mathrm{ICP}) \quad 0.004$

$19 \mathrm{Zr}(\mathrm{ICP}) \quad 0.032$

$20 \quad \mathrm{Ti}$ (ICP) 0.0395

$21 \quad \mathrm{~K}(\mathrm{AA}) \quad 0.1215$

$22 \mathrm{P}$ (ICP) 1.5475

$23 \quad \mathrm{P}$ (Calc IC) 0.975

$24 \quad \mathrm{Ba}$ (ICP) $\quad 0.008$

$25 \quad \mathrm{~Pb}$ (ICP) 0.161

26 Mo (ICP) 0.0105

$27 \quad \mathrm{Zn}$ (ICP) 0.9595

$28 \quad \mathrm{Cu}(\mathrm{ICP}) \quad 0.018$

29

$30 \quad \mathrm{~F}$ (ISE) $\quad<0.02$

$31 \quad \mathrm{Cl}$ (ISE) 0.1125

$32 \quad \mathrm{SO}^{4}$ (IC) $\quad<0.50$

$33 \quad \mathrm{NO}_{3}$ (IC) 14.275

$34 \mathrm{PO}_{4}(\mathrm{IC})^{* *} \quad 2.9885$

35

$36 \%$ SOLIDS $\left(105^{\circ} \mathrm{C}\right)$

$37 \%$ SOLIDS $\left(90^{\circ} \mathrm{C}\right)$

38

39 Moles of $\mathrm{Na}$

$40 \quad$ Moles of $\mathrm{NO}_{3}$

41 Moles of $\mathrm{Cl}$

\section{Column B}

$\underline{\text { Mass Balance Calculations }}$

0.325

$\mathbf{A l}(\mathbf{O H})_{3}$

$=((\mathrm{B} 3 / 26.98)-(\mathrm{B} 22 / 30.97))-$ $((\mathrm{B} 4 / 40.08) * 2) * 78$

$=\mathrm{B} 40 * 84.995$

$=((\mathrm{B} 14 / 28.08-(\mathrm{B} 4 / 40.08) / 6)) * 65$

$=((\mathrm{B} 17 / 238.029) / 7) * 2188.14$

$=(((\mathrm{B} 4 / 40.08) / 6)) *(2210)$

$=(\mathrm{B} 22 / 30.97) * 94.97$

$=\operatorname{SUM}(B 44: B 49)$
Excess moles

of $\mathrm{Na}$ over

$\mathrm{NaNO}_{3}+$

$\mathrm{Na}_{6} \mathrm{U}_{7} \mathrm{O}_{24}$
$=(\mathrm{B39}-\mathrm{B} 40-\mathrm{B} 41)-$ $(((\mathrm{B} 17 / 238.03) / 7) * 6)$
35.37

34.43

$=\mathrm{B} 8 / 22.9898$

$=\mathrm{B} 33 / 62.0049$

$=\mathrm{B} 31 / 35.453$ 
The mass balance summaries (Table V) agree with the concentrations of the phases predicted from the x-ray diffraction peak height analysis (Table VIII): Tanks 3 and 4 with low $\mathrm{pH}$ have less $\mathrm{Al}(\mathrm{OH})_{3}$ and only trace amount of $\mathrm{Na}_{6} \mathrm{U}_{7} \mathrm{O}_{24}$ while Tanks $1,2,5,6$, and 8 contain the most $\mathrm{Al}(\mathrm{OH})_{3}$ and $\mathrm{Na}_{6} \mathrm{U}_{7} \mathrm{O}_{24}$. All of the tanks have $\mathrm{NaNO}_{3}$ as the major species. Tank 10 has the largest fraction of filter aid and the lowest concentrations of $\mathrm{Na}_{6} \mathrm{U}_{7} \mathrm{O}_{24}$.

\section{AVERAGE M-AREA WASTE COMPOSITION}

M-Area sludge and spent filter aid was homogenized to form macrobatches of melter feed for the Vendor Treatment Facility (VTF). Using the measured tank volumes (Table II), the analyzed tank chemistry (Table V and Table VII), the analyzed wt\% solids (Table V), and the measured specific gravity of the wastes (Table X), an element contribution per tank can be calculated as follows:

$$
\begin{aligned}
\text { Dry element wt\%/tank }(\mathrm{Kgs})= & \text { Tank Volume }(\text { gal. }) \times(3.75 \mathrm{~L} / \text { gal. }) \times \text { Specific Gravity }(\mathrm{Kg} / \mathrm{L}) \mathrm{x} \\
& (\mathrm{wt} \% \text { solids })(\text { dry element } \mathrm{wt} \%)
\end{aligned}
$$

In a similar manner, the sludge-supernate composition of Tank 8 in Table IV can be used as an approximation of the supernate associated with the sludge in each tank (Table II and Table X), e.g. 95,000 gallons, the dry element wt\% contribution from the associated supernate can be calculated. The dry element wt $\%$ can then be summed over all the tanks for the sludge and supernate contributions. This can then be converted from element wt\% to oxide wt\% (Table XI) to determine what glass forming additives must be added. Note that Table XI does not include $\sim 3700$ gallons of slightly enriched $(1.1 \%) \mathrm{U}^{235}$ Mark 15 filter cake waste and $\sim 1200$ gallons of excess Watts Plating Line solution which was blended with the tank waste for final stabilization in the M-Area Vendor Treatment Facility (VTF).

\section{CONCLUSIONS}

M-Area sludge, supernate, crust, and filter aids were characterized. The sludge plus supernate is composed primarily of soluble sodium nitrate, aluminate and phosphate species. The chemical analyses, XRD analyses, and mass balance calculations demonstrated that $\mathrm{NaNO}_{3}, \mathrm{Na}_{6} \mathrm{U}_{7} \mathrm{O}_{24}$, $\mathrm{Al}(\mathrm{OH})_{3}, \mathrm{AlPO}_{4}$, a Ca-Na bearing Zeolite-A, and amorphous filter aids used in M-Area processing are the main constituents. The $\mathrm{Al}(\mathrm{OH})_{3}$ was the main constituent of the crust and the $\mathrm{NaNO}_{3}$ was the main component of the sludge. A minimum of three dissolutions and up to five different analytic methodologies were used to achieve each sludge/spent filter aid analysis. Mass balance calculations were used to verify the accuracy and consistency of the multiple chemical analyses. Many of the trace elements in the sludge are originating from the filter aids added during processing. The Zeolite-A forms in-situ in the tanks due to reaction of the silica rich filter aids with the aluminate bearing wastes in a high caustic environment.

The high concentrations of glass-forming species in the M-Area waste, e.g. Na, Al, Si and P, indicate that high waste loadings can be achieved during vitrification of this waste compared to solidification in cement. In addition, nitrate $\left(\mathrm{NO}_{3}\right)$ species volatilize during vitrification, mitigating nitrate leaching concerns normally associated with cementitious waste forms. 
Table X. Measured wt\% Solids and Specific Gravity of M-Area Tank Wastes

\begin{tabular}{|c|c|c|c|}
\hline TANK \# & $\begin{array}{c}\text { Sludge Volume } \\
\text { (Gallons) }\end{array}$ & $\begin{array}{c}\mathbf{W t}^{\prime} \% \text { Solids at } \\
\mathbf{1 0 5}^{\circ} \mathbf{C} \boldsymbol{\dagger}\end{array}$ & $\begin{array}{c}\text { Specific } \\
\text { Gravity } \\
\text { (Kg/L) }\end{array}$ \\
\hline 1 & 4,780 & 35 & $1.18^{*}$ \\
\hline 2 & 4,380 & 39 & $1.35^{*}$ \\
\hline 3 & 9,860 & 9 & $1.05^{*}$ \\
\hline 4 & 16,600 & 22 & $1.15^{*}$ \\
\hline 5 & 6,350 & 32 & $1.08^{*}$ \\
\hline 6 & 4,630 & 37 & $1.23^{*}$ \\
\hline 7 & 150,550 & 31 & $1.21^{* *}$ \\
\hline 8 & 160,750 & 38 & $1.24^{*}$ \\
\hline 10 & $\sim 270,100$ & 17 & $1.10^{* *}$ \\
\hline $\begin{array}{c}\text { Associated } \\
\text { Supernate }\end{array}$ & $\sim 95,000$ & 10 & $1.1^{* * *}$ \\
\hline
\end{tabular}

$\dagger$ measured in this study at $105^{\circ} \mathrm{C}$ (see Table V)

*Enwright Laboratories, Greenville, SC, Final Report for M-Area Sludge and Supernate Analyses: AX 0720919 (February 3, 1988)

**Estimated

*** Measured in this study (see Table IV Tank 8 average as an approximation) 
Table XI. M-Area Calculated Composite Sludge/Residual Supernate Composition. ${ }^{\dagger}$

\begin{tabular}{|c|c|c|c|}
\hline Oxide & Oxide Wt\% & Species & $\begin{array}{c}\text { Molar Mass } \\
\text { Balance }\end{array}$ \\
\hline $\mathrm{Al}_{2} \mathrm{O}_{3}$ & 20.27 & $\mathrm{Al}(\mathrm{OH})_{3}$ & 23.18 \\
\hline $\mathrm{CaO}$ & 0.59 & $\mathrm{NaNO}_{3}$ & 17.88 \\
\hline $\mathrm{Fe}_{2} \mathrm{O}_{3}$ & 0.96 & Filter Aid & 47.06 \\
\hline $\mathrm{MgO}$ & 0.24 & $\mathrm{Na}_{6} \mathrm{U}_{7} \mathrm{O}_{24}$ & 3.48 \\
\hline $\mathrm{MnO}$ & 0.37 & Ca Zeolite-A & 3.15 \\
\hline $\mathrm{Na}_{2} \mathrm{O}$ & 17.74 & $\mathrm{AlPO}_{4}$ & 4.32 \\
\hline $\mathrm{NiO}$ & 1.52 & SUM & 99.06 \\
\hline $\mathrm{SiO}_{2}$ & 47.48 & & \\
\hline $\mathrm{Cr}_{2} \mathrm{O}_{3}$ & 0.01 & & \\
\hline $\mathrm{B}_{2} \mathrm{O}_{3}$ & 0.06 & & \\
\hline $\mathrm{UO}_{2}$ & 4.21 & & \\
\hline $\mathrm{TiO}_{2}$ & 0.05 & & \\
\hline $\mathrm{K}_{2} \mathrm{O}$ & 1.28 & & \\
\hline $\mathrm{P}_{2} \mathrm{O}_{5}$ & 4.19 & & \\
\hline $\mathrm{BaO}$ & 0.03 & & \\
\hline $\mathrm{PbO}$ & 0.15 & & \\
\hline $\mathrm{MoO}_{3}$ & 0.01 & & \\
\hline $\mathrm{ZnO}$ & 0.77 & & \\
\hline $\mathrm{CuO}$ & 0.05 & & \\
\hline $\mathrm{SO}_{4}$ & 0.07 & & \\
\hline $\mathrm{NO}_{3}$ & 19.10 & & \\
\hline SUMS & 102.97 & & \\
\hline WT\% & 23.8 & & \\
\hline
\end{tabular}

$\dagger$ Calculated total inventory. Composition does not include $\sim 3700$ gallons of slightly enriched (1.1\%) $\mathrm{U}^{235}$ Mark 15 filter cake waste and $\sim 1200$ gallons of excess Watts Plating Line solution were homogenized with the tank waste for final stabilization in the M-Area Vendor Treatment Facility (VTF). 


\section{REFERENCES}

1 Federal Register, "Land Disposal Restrictions for Third Third Scheduled Wastes, Final Rule,” 55 FR22627 (June 1, 1990).

2 U.S. Environmental Protection Agency, "Handbook: Vitrification Technologies for Treatment of Hazardous and Radioactive Waste,” EPA/625/R-92/002 (May, 1992).

3 J. A. Stone, "PPC Program Proposals for FY-1989 and Beyond," U.S. DOE Report DPST-88-599, Savannah River Laboratory, E. I. duPont deNemours \& Co., Aiken, SC (1988).

4 C.M. Jantzen, J.B. Pickett, and W.G. Ramsey, "Reactive Additive Stabilization Process (RASP) for Hazardous and Mixed Waste Vitrification,". Proceedings of the Second International Symposium on Mixed Waste, A.A. Moghissi, R.K. Blauvelt, G.A. Benda, and N.E. Rothermich (Eds.), American Society of Mechanical Engineers, p.4.2.1 to 4.2 .13 (1993).

$5 \quad$ J.L.England and S. Shah, "Preliminary Planning Cost Estimate for Vitrification Alternatives of Mixed Waste," U.S. DOE Report WSRC-RP-92-1209, Westinghouse Savannah River Co., Aiken, SC (October 15, 1992).

6 D.F. Bickford, "Advanced Radioactive Waste-Glass Melters," Nuclear Waste Management IV, G.G. Wicks, D.F. Bickford, and L.R. Bunnell (Eds.), Ceramic Transactions, V. 23, American Ceramic Society, Westerville, OH, 335-347 (1991).

7 H. L. Martin, J.B. Pickett and C.A. Langton, "Radioactive and Hazardous Waste Sludge Treatment and Stabilization by Filtration," Am. Filtration Society 1992 National Meeting, May 1992, WSRC-MS-91- 235, Westinghouse Savannah River Co., Savannah River Site, Aiken, SC 29802 (1992).

8 J.B. Pickett, J.C. Musall, H.L. Martin, “Treatment and Disposal of Mixed F006 Plating Line Sludge at the Savannah River Site," Proceedings of the Second International Symposium on Mixed Waste," A.A. Moghissi, R.K. Blauvelt, G.A. Benda, and N.E. Rothermich (Eds.), American Society of Mechanical Engineers, 1.3.1-1.3.9 (1993).

$9 \quad$ SCDHEC Construction Permit \#14,832 (January 11, 1989).

10 B.W. Bowan, II and M.H. Clements, "Vendor Vitrification Programs for the Savannah River Site," Proceedings of the Second International Symposium on Mixed Waste, A.A. Moghissi, B.R. Love, R.K. Blauvelt (Eds.), American Society of Mechanical Engineers, p.8.4.1 to 8.4.8 (1995).

11 C.M. Jantzen, "Solidification of M-Area Sludge and Supernate Into Low Temperature Glass: Sludge and Supernate Characterization," U.S. DOE Report DPST-89-351, E.I. duPont deNemours \& Co., Aiken, SC (March 1, 1989). 
12 C.M. Jantzen, "Relationship of Glass Composition to Glass Viscosity, Resistivity, Liquidus Temperature, and Durability: First Principles Process-Product Models for Vitrification of Nuclear Waste," Proceedings of the $5^{\text {th }}$ International Symposium on Ceramics in Nuclear Waste Management, G.G. Wicks, D.F. Bickford, and R. Bunnell (Eds.), American Ceramic Society, Westerville, OH, 37-51 (1991).

13 C.M. Jantzen, J.B. Pickett, W.G. Ramsey, and D.C. Beam, "Treatability Studies on Mixed (Radioactive and Hazardous) M-Area F006 Waste Sludge: Vitrification Via the Reactive $\underline{\text { Additive }}$ Stabilization Process (RASP)," Proceedings of the International Topical Meeting on Nuclear and Hazardous Waste Management, Vol. I, Spectrum 1994, American Nuclear Society, La Grange Park, IL, 737-742 (1994).

14 G. L. Pine, and C.M. Jantzen, "Implications of a One-Year Basalt Weathering/ Reactivity Study for a Basalt Repository Environment," E.I. du Pont de Nemours \& Co., Savannah River Laboratory, DP-1742, 66p (March, 1987).

15 A. R. Jurgensen, DPSTM 87-700-6, ADD-1500, Revison 0 (1989).

16 M. Pourbaix, Atlas of Electrochemical Equilibria in Aqueous Solutions, English Translation of 1966 French version by J.A. Franklin (Ed)., National Association of Corrosion Engineers, Houston, TX, 644p (1974).

17 C. M. Jantzen, "Verification of Glass Composition and Strategy for SGM and DWPF Glass Composition Determination," DPST-86-708 (March 30, 1987).

18 E. H. P. Cordfunke and B O. Loopstra, "Sodium Uranates: Preparation and Thermochemical Properties," J. Inorgan. Chem., 33, 2427-2436 (1971).

19 C. A. Wamser, J. Belle, E. Bernsohn, and B. Williamson, "The Constitution of the Uranates of Sodium," J. Amer. Chem. Soc., 74, 1020-1022 (1952).

20 R.M. Barrer, J.W. Baynham, F.W. Bultitude and W.M. Meier, “Hydrothermal Chemistry of the Silicates. Part VIII. Low-temperature Growth of Aluminosilicates, and of some Gallium and Germanium Analogues,' J. Chem. Soc., 195-208 (1959). 
This page intentionally left blank. 


\begin{tabular}{|c|c|c|c|c|c|}
\hline Tank 1 & TK-1-1 & TK-1-2 & TK-1-1 & TK-1-2 & TANK 1 \\
\hline ANALYSIS \# & 111468 & 111469 & 21295 & 21296 & AVERAGE \\
\hline ANALYSIS DATE & $3 / 1 / 88$ & $3 / 1 / 88$ & $11 / 1 / 88$ & $11 / 1 / 88$ & \\
\hline RECORDED & DPSTN 4475 & DPSTN 4475 & DPSTN 4475 & DPSTN 4475 & \\
\hline $\mathrm{Al}(\mathrm{ICP})$ & 11.300 & 11.000 & 10.850 & 11.430 & 11.145 \\
\hline $\mathrm{Ca}(\mathrm{ICP})$ & 0.228 & 0.192 & 0.530 & 0.350 & 0.325 \\
\hline $\mathrm{Fe}(\mathrm{ICP})$ & $<0.004$ & $<0.004$ & 0.500 & 0.490 & 0.495 \\
\hline $\mathrm{Mg}(\mathrm{ICP})$ & 0.143 & 0.133 & 0.190 & 0.150 & 0.154 \\
\hline $\mathrm{Mn}(\mathrm{ICP})$ & 0.238 & 0.317 & 1.100 & 0.500 & 0.539 \\
\hline $\mathrm{Na}$ (ICP) & & & 8.810 & 8.850 & 8.830 \\
\hline $\mathrm{Na}(\mathrm{AA})$ & 10.010 & 9.140 & 8.590 & 8.100 & 8.960 \\
\hline Li (ICP) & $<0.002$ & $<0.002$ & $<0.002$ & $<0.002$ & $<0.002$ \\
\hline $\mathrm{Ni}(\mathrm{ICP})$ & & & 0.680 & 0.710 & 0.695 \\
\hline $\mathrm{Ni}$ (AA) & & & 0.884 & 0.868 & 0.876 \\
\hline Si (ICP) & 6.870 & 7.190 & 11.990 & 12.400 & 9.613 \\
\hline $\operatorname{Si}\left(A A^{*}\right)$ & 19.760 & 21.960 & 16.700 & 15.580 & 16.140 \\
\hline $\operatorname{Cr}(\mathrm{ICP})$ & 0.009 & 0.010 & 0.020 & 0.020 & 0.015 \\
\hline B (ICP) & $<0.002$ & $<0.002$ & 0.090 & 0.030 & 0.060 \\
\hline U (D-G) & 5.180 & 5.311 & & & 5.246 \\
\hline $\operatorname{Sr}(\mathrm{ICP})$ & 0.002 & 0.001 & 0.010 & $<0.001$ & 0.004 \\
\hline $\operatorname{Zr}(\mathrm{ICP})$ & 0.055 & 0.054 & 0.010 & 0.010 & 0.032 \\
\hline Ti (ICP) & 0.038 & 0.040 & 0.040 & 0.040 & 0.040 \\
\hline$K\left(A A^{*}\right)$ & & & 0.124 & 0.119 & 0.122 \\
\hline$P(I C P)^{\star \star \star}$ & 2.200 & 1.910 & 1.090 & 0.990 & 1.548 \\
\hline$P(\text { Calc IC })^{\star \star}$ & 1.040 & 0.909 & & & 0.975 \\
\hline $\mathrm{Ba}(\mathrm{ICP})$ & 0.008 & 0.007 & $<0.001$ & $<0.001$ & 0.008 \\
\hline $\mathrm{Pb}(\mathrm{ICP})$ & 0.048 & 0.086 & 0.320 & 0.190 & 0.161 \\
\hline Mo (ICP) & 0.012 & 0.010 & 0.010 & 0.010 & 0.011 \\
\hline $\mathrm{Zn}(\mathrm{ICP})$ & 0.618 & 0.580 & 1.760 & 0.880 & 0.960 \\
\hline $\mathrm{Cu}(\mathrm{ICP})$ & 0.013 & 0.009 & 0.020 & 0.030 & 0.018 \\
\hline$F(I S E)$ & $<0.02$ & $<0.02$ & & & $<0.02$ \\
\hline $\mathrm{Cl}$ (ISE) & 0.113 & 0.112 & & & 0.113 \\
\hline SO4 (IC) & $<0.09$ & $<0.50$ & & & $<0.50$ \\
\hline NO3 (IC) & 13.280 & 15.270 & & & 14.275 \\
\hline $\mathrm{PO} 4(\mathrm{IC})^{\star \star}$ & 3.190 & 2.787 & & & 2.989 \\
\hline$\%$ SOLIDS $\left(105^{\circ} \mathrm{C}\right)$ & 35.370 & & & & 35.370 \\
\hline$\%$ SOLIDS $\left(90^{\circ} \mathrm{C}\right)$ & 34.430 & & & & 34.430 \\
\hline Moles of $\mathrm{Na}$ & 0.435 & 0.398 & 0.374 & 0.352 & 0.390 \\
\hline Moles of NO3 & 0.214 & 0.246 & & & 0.230 \\
\hline Moles of $\mathrm{Cl}$ & 0.003 & 0.003 & & & 0.003 \\
\hline
\end{tabular}

*AA Silicon values in italics from $\mathrm{HCl} / \mathrm{HF}$ dissolution; others from $\mathrm{Na2O} 2$ dissolution all anions from $\mathrm{Na} 2 \mathrm{O} 2$ fusion with $\mathrm{H} 2 \mathrm{O}$ uptake (see text)

${ }^{* *}$ water soluble phosphate only; ${ }^{* * *}$ acid soluble phosphate

$\begin{array}{lr}\text { MASS BALANCE } & \\ \text { Al(OH)3 } & 27.06 \\ \text { NaNO3 } & 19.57 \\ \text { Filter Aid } & 36.31 \\ \text { Na6U7O24 } & 6.89 \\ \text { Ca-Zeolite-A } & 2.99 \\ \text { AlPO4 } & 4.75 \\ \text { SUM } & 97.55 \\ \text { EXCESS moles Na over } & \\ \text { NaNO3 and Na-U = } & 0.141\end{array}$




\begin{tabular}{|c|c|c|c|c|c|c|}
\hline Tank 2 & TK-2-1 & TK-2-2 & TK-2-1 & TK-2-2 & TANK 2 & TANK 2 \\
\hline ANALYSIS \# & 111470 & 111471 & 21297 & 21298 & AVERAGE & STANDARD \\
\hline ANALYSIS DATE & $3 / 1 / 88$ & $3 / 1 / 88$ & $11 / 1 / 88$ & $11 / 1 / 88$ & & DEVIATION \\
\hline RECORDED & DPSTN 4475 & DPSTN 4475 & DPSTN 4475 & DPSTN 4475 & & \\
\hline $\mathrm{Al}(\mathrm{ICP})$ & 8.010 & 7.490 & 6.710 & 6.310 & 7.130 & 0.764 \\
\hline $\mathrm{Ca}(\mathrm{ICP})$ & 0.119 & 0.112 & 0.450 & 0.560 & 0.310 & 0.229 \\
\hline $\mathrm{Fe}(\mathrm{ICP})$ & $<0.004$ & $<0.004$ & 0.270 & 0.250 & 0.260 & 0.014 \\
\hline $\mathrm{Mg}(\mathrm{ICP})$ & 0.028 & 0.024 & 0.120 & 0.130 & 0.076 & 0.057 \\
\hline $\mathrm{Mn}(\mathrm{ICP})$ & $<0.004$ & $<0.004$ & 1.300 & 1.330 & 1.315 & 0.021 \\
\hline $\mathrm{Na}$ (ICP) & & & 12.470 & 12.390 & 12.430 & 0.057 \\
\hline $\mathrm{Na}\left(\mathrm{AA}^{\star}\right)$ & 14.780 & 15.360 & 13.780 & 13.530 & 14.363 & 0.857 \\
\hline Li (ICP) & $<0.002$ & $<0.002$ & $<0.002$ & $<0.002$ & $<0.002$ & \\
\hline $\mathrm{Ni}(\mathrm{ICP})$ & & & 0.390 & 0.390 & 0.390 & 0.000 \\
\hline $\mathrm{Ni}\left(\mathrm{AA}^{*}\right)$ & & & 0.566 & 0.546 & 0.556 & 0.014 \\
\hline Si (ICP) & 2.540 & 2.430 & 2.290 & 2.370 & 2.408 & 0.105 \\
\hline $\operatorname{Si}\left(\mathrm{AA}^{*}\right)$ & 11.670 & 9.770 & 3.040 & 3.240 & 3.140 & 0.141 \\
\hline $\mathrm{Cr}(\mathrm{ICP})$ & 0.007 & 0.006 & 0.020 & 0.020 & 0.013 & 0.008 \\
\hline B (ICP) & $<0.002$ & $<0.002$ & 0.080 & 0.070 & 0.075 & 0.007 \\
\hline U (D-G) & 4.718 & 4.853 & & & 4.786 & 0.095 \\
\hline $\mathrm{Sr}(\mathrm{ICP})$ & 0.002 & 0.002 & 0.001 & 0.010 & 0.004 & 0.004 \\
\hline $\mathrm{Zr}(\mathrm{ICP})$ & $<0.002$ & $<0.002$ & 0.010 & 0.010 & 0.010 & 0.000 \\
\hline $\mathrm{Ti}$ (ICP) & 0.009 & 0.008 & 0.020 & 0.020 & 0.014 & 0.007 \\
\hline$K\left(A A^{*}\right)$ & & & 0.033 & 0.032 & 0.033 & 0.001 \\
\hline$P(I C P)^{\star \star *}$ & 2.260 & 1.780 & 0.920 & 0.900 & 1.465 & 0.670 \\
\hline$P(\text { Calc IC })^{* *}$ & 0.789 & 0.760 & & & 0.774 & 0.020 \\
\hline $\mathrm{Ba}(\mathrm{ICP})$ & 0.031 & 0.003 & $<0.001$ & $<0.001$ & 0.017 & 0.020 \\
\hline $\mathrm{Pb}(\mathrm{ICP})$ & 0.059 & 0.074 & 0.350 & 0.370 & 0.213 & 0.170 \\
\hline Mo (ICP) & $<0.004$ & $<0.004$ & 0.010 & 0.010 & 0.010 & 0.000 \\
\hline $\mathrm{Zn}(\mathrm{ICP})$ & $<0.004$ & $<0.004$ & 2.130 & 2.180 & 2.155 & 0.035 \\
\hline $\mathrm{Cu}(\mathrm{ICP})$ & 0.011 & 0.012 & 0.020 & 0.020 & 0.016 & 0.005 \\
\hline$F(I S E)$ & $<0.265$ & $<0.265$ & & & $<0.265$ & \\
\hline $\mathrm{Cl}$ (ISE) & 0.191 & 0.187 & & & 0.189 & 0.003 \\
\hline SO4 (IC) & $<0.5$ & $<0.5$ & & & $<0.5$ & \\
\hline NO3 (IC) & 34.970 & 34.350 & & & 34.660 & 0.438 \\
\hline $\mathrm{PO} 4(\mathrm{IC})^{\star *}$ & 2.418 & 2.332 & & & 2.375 & 0.061 \\
\hline \% SOLIDS $\left(105^{\circ} \mathrm{C}\right)$ & 38.980 & & & & 38.980 & \\
\hline$\%$ SOLIDS $\left(90^{\circ} \mathrm{C}\right)$ & 38.540 & & & & 38.540 & \\
\hline Moles of $\mathrm{Na}$ & 0.643 & 0.668 & 0.599 & 0.589 & 0.625 & 0.037 \\
\hline Moles of NO3 & 0.564 & 0.554 & & & 0.559 & 0.007 \\
\hline Moles of $\mathrm{Cl}$ & 0.005 & 0.005 & & & 0.005 & 0.000 \\
\hline
\end{tabular}

*AA Silicon values in italics from $\mathrm{HCl} / \mathrm{HF}$ dissolution; others from $\mathrm{Na} 2 \mathrm{O} 2$ dissolution all anions from $\mathrm{Na} 2 \mathrm{O} 2$ fusion with $\mathrm{H} 2 \mathrm{O}$ uptake (see text)

${ }^{* *}$ water soluble phosphate only; ${ }^{* * *}$ acid soluble phosphate

$\begin{array}{lr}\text { MOLAR MASS BALANCE } & \\ \mathrm{Al}(\mathrm{OH}) 3 & 15.716 \\ \mathrm{NaNO3} & 47.511 \\ \mathrm{SiO} 2 \text { as Filter Aid } & 5.789 \\ \mathrm{Na6U7O24} & 6.285 \\ \text { Ca-zeolite } & 2.851 \\ \text { AlPO4 } & 4.492 \\ \text { SUM } & 82.644 \\ \text { EXCESS moles } \mathrm{Na} \text { over } & \\ \text { NaNO3 and Na-U = } & 0.049\end{array}$




\begin{tabular}{|c|c|c|c|c|c|c|}
\hline Tank 3 & TK-3-1 & TK-3-2 & TK-3-1 & TK-3-2 & TANK 3 & TANK 3 \\
\hline ANALYSIS \# & 111472 & 111473 & 21299 & 21300 & AVERAGE & STANDARD \\
\hline ANALYSIS DATE & $3 / 1 / 88$ & $3 / 1 / 88$ & $11 / 1 / 88$ & $11 / 1 / 88$ & & DEVIATION \\
\hline RECORDED & DPSTN 4475 & DPSTN 4475 & DPSTN 4475 & DPSTN 4475 & & \\
\hline $\mathrm{Al}(\mathrm{ICP})$ & 6.600 & 5.240 & 4.050 & 9.640 & 6.383 & 2.409 \\
\hline Ca (ICP) & 0.154 & 0.171 & 0.600 & 0.290 & 0.304 & 0.207 \\
\hline $\mathrm{Fe}(\mathrm{ICP})$ & $<0.004$ & $<0.004$ & 0.310 & 1.000 & 0.655 & 0.488 \\
\hline $\mathrm{Mg}(\mathrm{ICP})$ & 0.035 & 0.019 & 0.150 & 0.070 & 0.069 & 0.058 \\
\hline $\mathrm{Mn}(\mathrm{ICP})$ & $<0.004$ & $<0.004$ & 1.510 & 0.540 & 1.025 & 0.686 \\
\hline $\mathrm{Na}$ (ICP) & & & 15.370 & 15.480 & 15.425 & 0.078 \\
\hline $\mathrm{Na}\left(\mathrm{AA}^{*}\right)$ & 16.700 & 15.260 & 16.910 & 17.980 & 16.713 & 1.119 \\
\hline $\mathrm{Li}(\mathrm{ICP})$ & $<0.002$ & $<0.002$ & $<0.002$ & $<0.002$ & $<0.002$ & \\
\hline $\mathrm{Ni}$ (ICP) & & & 0.300 & 0.250 & 0.275 & 0.035 \\
\hline $\mathrm{Ni}\left(\mathrm{AA}^{*}\right)$ & & & 0.423 & 0.346 & 0.385 & 0.054 \\
\hline Si (ICP) & 5.060 & 3.640 & 3.280 & 2.720 & 3.675 & 0.998 \\
\hline Si $\left(\mathbf{A A}^{\star}\right)$ & 10.200 & 11.830 & 4.550 & 3.660 & 4.105 & 0.629 \\
\hline $\mathrm{Cr}(\mathrm{ICP})$ & $<0.004$ & $<0.004$ & 0.010 & 0.010 & 0.010 & 0.000 \\
\hline B (ICP) & $<0.002$ & $<0.002$ & 0.040 & 0.010 & 0.025 & 0.021 \\
\hline U (D-G) & 3.023 & 3.434 & & & 3.229 & 0.291 \\
\hline $\operatorname{Sr}(I C P)$ & 0.002 & 0.002 & 0.010 & $<0.0005$ & 0.005 & 0.005 \\
\hline $\operatorname{Zr}(\mathrm{ICP})$ & $<0.002$ & $<0.002$ & 0.010 & 0.010 & 0.010 & 0.000 \\
\hline Ti (ICP) & 0.005 & $<0.001$ & 0.020 & 0.020 & 0.015 & 0.009 \\
\hline $\mathrm{K}\left(\mathrm{AA}^{*}\right)$ & & & 0.057 & 0.051 & 0.054 & 0.004 \\
\hline$P(I C P)^{\star \star \star}$ & 2.320 & 2.170 & 1.280 & 2.040 & 1.953 & 0.463 \\
\hline$P(\text { Calc IC })^{\star *}$ & 1.255 & 1.327 & & & 1.291 & 0.051 \\
\hline $\mathrm{Ba}(\mathrm{ICP})$ & 0.031 & 0.029 & $<0.001$ & $<0.001$ & 0.030 & 0.001 \\
\hline $\mathrm{Pb}(\mathrm{ICP})$ & 0.019 & 0.017 & 0.390 & 0.200 & 0.157 & 0.178 \\
\hline Mo (ICP) & $<0.004$ & $<0.004$ & 0.010 & 0.010 & 0.010 & 0.000 \\
\hline Zn (ICP) & $<0.004$ & $<0.004$ & 2.450 & 0.990 & 1.720 & 1.032 \\
\hline $\mathrm{Cu}(\mathrm{ICP})$ & 0.009 & 0.007 & 0.010 & 0.030 & 0.014 & 0.011 \\
\hline$F(I S E)$ & $<0.02$ & $<0.02$ & & & $<0.02$ & \\
\hline $\mathrm{Cl}$ (ISE) & 0.142 & 0.143 & & & 0.142 & 0.001 \\
\hline SO4 (IC) & $<0.5$ & $<2.0$ & & & $<0.5$ & \\
\hline NO3 (IC) & 49.500 & 51.660 & & & 50.580 & 1.527 \\
\hline $\mathrm{PO} 4(\mathrm{IC})^{\star *}$ & 3.850 & 4.070 & & & 3.960 & 0.156 \\
\hline \% SOLIDS $\left(105^{\circ} \mathrm{C}\right)$ & 9.240 & & & & 9.240 & \\
\hline$\%$ SOLIDS $\left(90^{\circ} \mathrm{C}\right)$ & 6.800 & & & & 6.800 & \\
\hline Moles of $\mathrm{Na}$ & 0.726 & 0.664 & 0.736 & 0.782 & 0.727 & 0.049 \\
\hline Moles of NO3 & 0.798 & 0.833 & & & 0.816 & 0.025 \\
\hline Moles of $\mathrm{Cl}$ & 0.004 & 0.004 & & & 0.004 & 0.000 \\
\hline
\end{tabular}

${ }^{*} \mathrm{AA}$ Silicon values in italics from $\mathrm{HCl} / \mathrm{HF}$ dissolution; others from $\mathrm{Na2O}$ dissolution all anions from $\mathrm{Na} 2 \mathrm{O} 2$ fusion with $\mathrm{H} 2 \mathrm{O}$ uptake (see text)

${ }^{* *}$ water soluble phosphate only; ${ }^{* * *}$ acid soluble phosphate

$\begin{array}{lr}\text { MASS BALANCE SPECIATION } & \\ \text { Al(OH)3 } & 12.35 \\ \text { NaNO3 } & 69.33 \\ \text { Filter Aid } & 8.52 \\ \text { Na6U7O24 } & 4.24 \\ \text { Ca-Zeolite-A } & 2.79 \\ \text { AIPO4 } & 5.99 \\ \text { SUM } & 103.222 \\ \text { EXCESS moles Na over } & \\ \text { NaNO3 and Na-U = } & -0.100\end{array}$




\begin{tabular}{|c|c|c|c|c|c|c|}
\hline Tank 4 & TK-4-1 & TK-4-2 & TK-4-1 & TK-4-2 & TANK 4 & TANK 4 \\
\hline ANALYSIS \# & 111474 & 111475 & 21301 & 21302 & AVERAGE & STANDARD \\
\hline ANALYSIS DATE & 3/1/88 & 3/1/88 & $11 / 1 / 88$ & $11 / 1 / 88$ & & DEVIATION \\
\hline RECORDED & DPSTN 4475 & DPSTN 4475 & DPSTN 4475 & DPSTN 4475 & & \\
\hline $\mathrm{Al}(\mathrm{ICP})$ & 1.730 & 1.200 & 0.990 & 8.250 & 3.043 & 3.486 \\
\hline $\mathrm{Ca}(\mathrm{ICP})$ & 0.108 & 0.030 & 0.420 & 0.260 & 0.205 & 0.173 \\
\hline $\mathrm{Fe}(\mathrm{ICP})$ & $<0.004$ & $<0.004$ & 0.040 & 0.390 & 0.215 & 0.247 \\
\hline $\mathrm{Mg}(\mathrm{ICP})$ & 0.059 & 0.040 & 0.100 & 0.080 & 0.070 & 0.026 \\
\hline $\mathrm{Mn}(\mathrm{ICP})$ & 0.682 & 0.465 & 1.320 & 0.470 & 0.734 & 0.403 \\
\hline $\mathrm{Na}$ (ICP) & & & 21.110 & 22.000 & 21.555 & 0.629 \\
\hline $\mathrm{Na}(\mathrm{AA})$ & 24.180 & 24.080 & 26.060 & 27.420 & 25.435 & 1.606 \\
\hline $\mathrm{Li}(\mathrm{ICP})$ & $<0.002$ & $<0.002$ & $<0.002$ & $<0.002$ & $<0.002$ & \\
\hline $\mathrm{Ni}(\mathrm{ICP})$ & & & 0.080 & 0.030 & 0.055 & 0.035 \\
\hline $\mathrm{Ni}(\mathrm{AA})$ & & & 0.114 & 0.050 & 0.082 & 0.045 \\
\hline Si (ICP) & 1.070 & 0.742 & 0.560 & 4.150 & 1.631 & 1.693 \\
\hline Si (AA) & 2.560 & 2.350 & 0.826 & 5.820 & 3.323 & 3.531 \\
\hline $\mathrm{Cr}$ (ICP) & $<0.004$ & $<0.004$ & 0.010 & 0.020 & 0.015 & 0.007 \\
\hline B (ICP) & $<0.002$ & $<0.002$ & 0.020 & 0.010 & 0.015 & 0.007 \\
\hline U (D-G) & 1.321 & 1.240 & & & 1.281 & 0.057 \\
\hline $\operatorname{Sr}(I C P)$ & 0.002 & $<0.001$ & $<0.0005$ & $<0.0005$ & 0.002 & \\
\hline $\mathrm{Zr}$ (ICP) & 0.138 & 0.093 & 0.010 & $<0.004$ & 0.080 & 0.065 \\
\hline $\mathrm{Ti}(\mathrm{ICP})$ & 0.023 & 0.015 & 0.010 & 0.020 & 0.017 & 0.006 \\
\hline$K(A A)$ & & & 0.023 & 0.018 & 0.021 & 0.004 \\
\hline$P(I C P)^{\star \star \star}$ & 1.210 & 1.100 & 0.270 & 2.610 & 1.298 & 0.970 \\
\hline$P(\text { Calc IC })^{\star \star}$ & 0.320 & 0.432 & & & 0.376 & 0.079 \\
\hline $\mathrm{Ba}(\mathrm{ICP})$ & 0.033 & 0.031 & $<0.001$ & $<0.001$ & 0.032 & 0.001 \\
\hline $\mathrm{Pb}(\mathrm{ICP})$ & 0.046 & 0.016 & 0.320 & 0.160 & 0.136 & 0.138 \\
\hline Mo (ICP) & 0.013 & 0.007 & 0.010 & 0.010 & 0.010 & 0.002 \\
\hline $\mathrm{Zn}(\mathrm{ICP})$ & 1.340 & 0.927 & 2.100 & 0.810 & 1.294 & 0.583 \\
\hline $\mathrm{Cu}(\mathrm{ICP})$ & $<0.004$ & $<0.004$ & 0.010 & 0.030 & 0.020 & 0.014 \\
\hline$F(I S E)$ & $<0.02$ & $<0.02$ & & & $<0.02$ & \\
\hline $\mathrm{Cl}$ (ISE) & 0.171 & 0.269 & & & 0.220 & 0.069 \\
\hline SO4 (IC) & $<0.5$ & $<0.5$ & & & $<0.5$ & \\
\hline NO3 (IC) & 50.000 & 69.000 & & & 59.500 & 13.435 \\
\hline $\mathrm{PO} 4(\mathrm{IC})^{* *}$ & 0.980 & 1.324 & & & 1.152 & 0.243 \\
\hline$\%$ SOLIDS $\left(105^{\circ} \mathrm{C}\right)$ & 22.340 & & & & 22.340 & \\
\hline$\%$ SOLIDS $\left(90^{\circ} \mathrm{C}\right)$ & 19.870 & & & & 19.870 & \\
\hline Moles of $\mathrm{Na}$ & 1.052 & 1.047 & 1.134 & 1.193 & 1.106 & 0.070 \\
\hline Moles of NO3 & 0.806 & 1.113 & & & 0.960 & 0.217 \\
\hline Moles of $\mathrm{Cl}$ & 0.005 & 0.008 & & & 0.006 & 0.002 \\
\hline
\end{tabular}

*AA Silicon values in italics from $\mathrm{HCl} / \mathrm{HF}$ dissolution; others from $\mathrm{Na} 2 \mathrm{O} 2$ dissolution all anions from $\mathrm{Na} 2 \mathrm{O} 2$ fusion with $\mathrm{H} 2 \mathrm{O}$ uptake (see text)

${ }^{* *}$ water soluble phosphate only; ${ }^{* * *}$ acid soluble phosphate

MASS BALANCE SPECIATION

$\begin{array}{lr}\text { Al(OH)3 } & 4.73 \\ \text { NaNO3 } & 81.56 \\ \text { Filter Aid } & 7.03 \\ \text { Na6U7O24 } & 1.68 \\ \text { Ca-Zeolite-A } & 1.88 \\ \text { AlPO4 } & 3.98 \\ \text { SUM } & 100.862 \\ \text { EXCESS moles Na over } & \\ \text { NaNO3 and } \mathrm{Na}-\mathrm{U}= & 0.142\end{array}$




\begin{tabular}{|c|c|c|c|c|c|c|}
\hline Tank 5 & TK-5-1 & TK-5-2 & TK-5-2 & TK-5-2 & TANK 5 & TANK 5 \\
\hline ANALYSIS \# & 111476 & 111477 & 21303 & 21304 & AVERAGE & STANDARD \\
\hline ANALYSIS DATE & $3 / 1 / 88$ & $3 / 1 / 88$ & $11 / 1 / 88$ & $11 / 1 / 88$ & & DEVIATION \\
\hline RECORDED & DPSTN 4475 & DPSTN 4475 & DPSTN 4475 & DPSTN 4725 & & \\
\hline $\mathrm{Al}(\mathrm{ICP})$ & 9.540 & 9.600 & 10.000 & 9.970 & 9.778 & 0.241 \\
\hline $\mathrm{Ca}(\mathrm{ICP})$ & 0.151 & 0.375 & 0.410 & 0.370 & 0.327 & 0.118 \\
\hline $\mathrm{Fe}(\mathrm{ICP})$ & $<0.004$ & $<0.005$ & 0.510 & 0.480 & 0.495 & 0.021 \\
\hline $\mathrm{Mg}(\mathrm{ICP})$ & 0.094 & 0.102 & 0.180 & 0.170 & 0.137 & 0.045 \\
\hline $\mathrm{Mn}(\mathrm{ICP})$ & 0.027 & $<0.005$ & 0.660 & 0.490 & 0.392 & 0.328 \\
\hline $\mathrm{Na}$ (ICP) & & & 11.090 & 9.940 & 10.515 & 0.813 \\
\hline $\mathrm{Na}(\mathrm{AA})$ & 10.940 & 10.600 & 11.580 & 9.750 & 10.718 & 0.762 \\
\hline Li (ICP) & $<0.002$ & $<0.002$ & $<0.002$ & $<0.002$ & $<0.002$ & \\
\hline $\mathrm{Ni}(\mathrm{ICP})$ & & & 0.560 & 0.550 & 0.555 & 0.007 \\
\hline $\mathrm{Ni}(\mathrm{AA})$ & & & 0.777 & 0.739 & 0.758 & 0.027 \\
\hline Si (ICP) & 10.200 & 10.300 & 11.410 & 11.250 & 10.790 & 0.628 \\
\hline Si (AA) & 14.210 & 10.080 & 13.990 & 14.070 & 14.030 & 0.057 \\
\hline $\mathrm{Cr}(\mathrm{ICP})$ & $<0.004$ & $<0.005$ & 0.020 & 0.010 & 0.015 & 0.007 \\
\hline B (ICP) & $<0.002$ & $<0.002$ & 0.020 & 0.010 & 0.015 & 0.007 \\
\hline U (D-G) & 4.180 & 3.536 & & & 3.858 & 0.455 \\
\hline $\mathrm{Sr}(\mathrm{ICP})$ & 0.002 & 0.004 & $<0.0005$ & $<0.0005$ & 0.003 & 0.001 \\
\hline $\mathrm{Zr}(\mathrm{ICP})$ & $<0.002$ & $<0.002$ & 0.010 & 0.010 & 0.010 & 0.000 \\
\hline $\mathrm{Ti}(\mathrm{ICP})$ & 0.024 & 0.029 & 0.040 & 0.040 & 0.033 & 0.008 \\
\hline$K(A A)$ & & & 0.110 & 0.097 & 0.104 & 0.009 \\
\hline$P(I C P)^{\star \star \star}$ & 1.570 & 2.200 & 0.670 & 0.640 & 1.270 & 0.755 \\
\hline$P(\text { Calc IC })^{\star \star}$ & $<0.848$ & $\mathrm{~N} / \mathrm{A}$ & & & & \\
\hline $\mathrm{Ba}(\mathrm{ICP})$ & 0.029 & 0.036 & 0.000 & 0.000 & 0.016 & 0.019 \\
\hline $\mathrm{Pb}(\mathrm{ICP})$ & 0.031 & $<0.014$ & 0.190 & 0.150 & 0.124 & 0.083 \\
\hline Mo (ICP) & $<0.004$ & $<0.005$ & 0.010 & 0.010 & 0.010 & 0.000 \\
\hline $\mathrm{Zn}(\mathrm{ICP})$ & $<0.004$ & $<0.005$ & 1.070 & 0.820 & 0.945 & 0.177 \\
\hline $\mathrm{Cu}(\mathrm{ICP})$ & 0.005 & 0.009 & 0.010 & 0.010 & 0.009 & 0.002 \\
\hline F (ISE) & $<0.02$ & $<0.02$ & & & $<0.02$ & \\
\hline $\mathrm{Cl}$ (ISE) & 0.843 & $\mathrm{~N} / \mathrm{A}$ & & & 0.843 & \\
\hline SO4 (IC) & $<1.31$ & $\mathrm{~N} / \mathrm{A}$ & & & $<1.31$ & \\
\hline NO3 (IC) & 12.000 & $\mathrm{~N} / \mathrm{A}$ & & & 12.000 & \\
\hline $\mathrm{PO} 4(\mathrm{IC})^{\star *}$ & $<2.6$ & $\mathrm{~N} / \mathrm{A}$ & & & $<2.6$ & \\
\hline$\%$ SOLIDS $\left(105^{\circ} \mathrm{C}\right)$ & 32.490 & & & & 32.490 & \\
\hline$\%$ SOLIDS $\left(90^{\circ} \mathrm{C}\right)$ & 28.290 & & & & 28.290 & \\
\hline Moles of $\mathrm{Na}$ & 0.476 & 0.461 & 0.504 & 0.424 & 0.466 & 0.033 \\
\hline Moles of $\mathrm{NO} 3$ & 0.194 & $\mathrm{~N} / \mathrm{A}$ & & & 0.194 & \\
\hline Moles of $\mathrm{Cl}$ & 0.024 & $N / A$ & & & 0.024 & \\
\hline \multicolumn{7}{|c|}{$\begin{array}{l}\text { *AA Silicon values in italics from } \mathrm{HCl} / \mathrm{HF} \text { dissolution; others from } \mathrm{Na} 2 \mathrm{O} 2 \text { dissolution } \\
\text { all anions from } \mathrm{Na} 2 \mathrm{O} 2 \text { fusion with } \mathrm{H} 2 \mathrm{O} \text { uptake (see text) }\end{array}$} \\
\hline \multicolumn{7}{|c|}{${ }^{\star *}$ water soluble phosphate only; ${ }^{* * *}$ acid soluble phosphate } \\
\hline \multicolumn{7}{|c|}{ MASS BALANCE SPECIATION } \\
\hline \multirow{2}{*}{\multicolumn{5}{|c|}{$\begin{array}{l}\mathrm{Al}(\mathrm{OH}) 3 \\
\mathrm{NaNO} 3\end{array}$}} & 23.798 & \\
\hline & & & & & 16.449 & \\
\hline \multicolumn{5}{|c|}{ SiO2 as Filter Aid } & 29.042 & \\
\hline \multicolumn{5}{|c|}{ Na6U7O24 } & 5.067 & \\
\hline \multicolumn{5}{|c|}{ Ca-zeolite } & 3.001 & \\
\hline \multicolumn{5}{|c|}{ AIPO4 } & 3.894 & \\
\hline & & & SUM & & 81.251 & \\
\hline \multicolumn{7}{|c|}{ EXCESS moles $\mathrm{Na}$ over } \\
\hline \multicolumn{5}{|c|}{$\mathrm{NaNO} 3$ and $\mathrm{Na}-\mathrm{U}=$} & 0.259 & \\
\hline
\end{tabular}




\begin{tabular}{|c|c|c|c|c|c|c|}
\hline Tank 6 & TK-6-1 & TK-6-2 & TK-6-1 & TK-6-2 & TANK 6 & TANK 6 \\
\hline ANALYSIS \# & 111478 & 111479 & $21305 \& 6$ & 21307 & AVERAGE & STANDARD \\
\hline ANALYSIS DATE & $3 / 1 / 88$ & $3 / 1 / 88$ & $11 / 1 / 88$ & $11 / 1 / 88$ & & DEVIATION \\
\hline RECORDED & DPSTN 4475 & DPSTN 4475 & DPSTN 4725 & DPSTN 4725 & & \\
\hline $\mathrm{Al}(\mathrm{ICP})$ & 9.870 & 9.740 & 11.020 & 9.420 & 10.013 & 0.698 \\
\hline $\mathrm{Ca}(\mathrm{ICP})$ & 0.203 & 0.195 & 1.180 & 0.410 & 0.497 & 0.466 \\
\hline $\mathrm{Fe}(\mathrm{ICP})$ & $<0.004$ & $<0.004$ & 0.850 & 0.630 & 0.740 & 0.156 \\
\hline $\mathrm{Mg}(\mathrm{ICP})$ & 0.102 & 0.101 & 0.350 & 0.200 & 0.188 & 0.117 \\
\hline $\mathrm{Mn}(\mathrm{ICP})$ & BDL & BDL & 2.650 & 0.420 & 1.535 & 1.577 \\
\hline $\mathrm{Na}$ (ICP) & & & 11.000 & 8.340 & 9.670 & 1.881 \\
\hline $\mathrm{Na}(\mathrm{AA})$ & 9.480 & 9.180 & 11.980 & 10.270 & 10.228 & 1.256 \\
\hline Li (ICP) & $<0.002$ & $<0.002$ & $<0.002$ & $<0.002$ & $<0.002$ & \\
\hline $\mathrm{Ni}(\mathrm{ICP})$ & & & 0.430 & 0.420 & 0.425 & 0.007 \\
\hline $\mathrm{Ni}$ (AA) & & & 0.604 & 0.597 & 0.601 & 0.005 \\
\hline Si (ICP) & 10.800 & 10.700 & 11.750 & 15.990 & 12.310 & 2.499 \\
\hline Si (AA) & 14.760 & 13.190 & 17.800 & 18.200 & 18.000 & 0.283 \\
\hline $\mathrm{Cr}(\mathrm{ICP})$ & $<0.004$ & $<0.004$ & 0.020 & 0.020 & 0.020 & 0.000 \\
\hline B (ICP) & $<0.002$ & $<0.002$ & $<0.009$ & 0.010 & 0.010 & \\
\hline U (D-G) & 4.519 & 3.640 & & & 4.080 & 0.622 \\
\hline $\mathrm{Sr}(\mathrm{ICP})$ & 0.004 & 0.004 & 0.010 & $<0.0005$ & 0.006 & 0.003 \\
\hline $\mathrm{Zr}(\mathrm{ICP})$ & $<0.002$ & $<0.002$ & 0.010 & 0.010 & 0.010 & 0.000 \\
\hline $\mathrm{Ti}(\mathrm{ICP})$ & 0.026 & 0.026 & 0.050 & 0.050 & 0.038 & 0.014 \\
\hline$K(A A)$ & & & 0.108 & 0.106 & 0.107 & 0.001 \\
\hline$P(I C P)^{\star \star \star}$ & 1.680 & 1.520 & 0.650 & 0.690 & 1.135 & 0.541 \\
\hline$P(\text { Calc IC })^{\star \star}$ & 0.233 & 0.255 & & & 0.244 & 0.016 \\
\hline $\mathrm{Ba}(\mathrm{ICP})$ & 0.048 & 0.046 & $<0.001$ & $<0.001$ & 0.047 & 0.001 \\
\hline $\mathrm{Pb}(\mathrm{ICP})$ & 0.048 & 0.021 & 0.760 & 0.150 & 0.245 & 0.348 \\
\hline Mo (ICP) & $<0.004$ & $<0.004$ & 0.020 & 0.010 & 0.015 & 0.007 \\
\hline $\mathrm{Zn}(\mathrm{ICP})$ & $<0.004$ & $<0.004$ & 5.000 & 0.750 & 2.875 & 3.005 \\
\hline $\mathrm{Cu}$ (ICP) & 0.012 & 0.010 & 0.040 & 0.040 & 0.026 & 0.017 \\
\hline $\mathrm{F}$ (ISE) & $<0.02$ & $\mathrm{~N} / \mathrm{A}$ & & & $<0.02$ & \\
\hline $\mathrm{Cl}$ (ISE) & 0.060 & 0.060 & & & 0.060 & 0.000 \\
\hline SO4 (IC) & $<0.5$ & $<0.5$ & & & $<0.5$ & \\
\hline NO3 (IC) & 12.650 & 13.090 & & & 12.870 & 0.311 \\
\hline $\mathrm{PO} 4(\mathrm{IC})^{\star *}$ & 0.715 & 0.783 & & & 0.749 & 0.048 \\
\hline$\%$ SOLIDS $\left(105^{\circ} \mathrm{C}\right)$ & 37.120 & & & & 37.120 & \\
\hline$\%$ SOLIDS $\left(90^{\circ} \mathrm{C}\right)$ & 36.980 & & & & 36.980 & \\
\hline Moles of $\mathrm{Na}$ & 0.412 & 0.399 & 0.521 & 0.447 & 0.445 & 0.055 \\
\hline Moles of NO3 & 0.204 & 0.211 & & & 0.208 & 0.005 \\
\hline Moles of $\mathrm{Cl}$ & 0.002 & 0.002 & & & 0.002 & 0.000 \\
\hline
\end{tabular}

${ }^{*} \mathrm{AA}$ Silicon values in italics from $\mathrm{HCl} / \mathrm{HF}$ dissolution; others from $\mathrm{Na2O} 2$ dissolution all anions from $\mathrm{Na} 2 \mathrm{O} 2$ fusion with $\mathrm{H} 2 \mathrm{O}$ uptake (see text)

${ }^{* *}$ water soluble phosphate only; ${ }^{* * *}$ acid soluble phosphate

MASS BALANCE SPECIATION

$\begin{array}{lr}\mathrm{Al}(\mathrm{OH}) 3 & 24.15 \\ \mathrm{NaNO3} & 17.64 \\ \text { Filter Aid } & 40.05 \\ \mathrm{Na6U7O24} & 5.36 \\ \text { Ca-Zeolite-A } & 4.57 \\ \text { AIPO4 } & 3.48 \\ \text { SUM } & 95.26 \\ \text { EXCESS moles Na over } & \\ \text { NaNO3 and Na-U = } & 0.223\end{array}$




\begin{tabular}{|c|c|c|}
\hline Tank 7 & TK-7-1 & TK-7-2 \\
\hline ANALYSIS \# & 200076566 & 200076567 \\
\hline ANALYSIS DATE & $5 / 12 / 92$ & $5 / 12 / 92$ \\
\hline RECORDED & DPSTN 4725 & DPSTN 4725 \\
\hline $\mathrm{Al}(\mathrm{ICP})$ & 6.236 & 6.549 \\
\hline $\mathrm{Ca}(\mathrm{ICP})$ & 0.576 & 0.264 \\
\hline $\mathrm{Fe}(\mathrm{ICP})$ & 0.456 & 0.601 \\
\hline $\mathrm{Mg}(\mathrm{ICP})$ & 0.136 & 0.115 \\
\hline $\mathrm{Mn}(\mathrm{ICP})$ & 0.006 & 0.003 \\
\hline $\mathrm{Na}$ (ICP) & 12.863 & 11.720 \\
\hline $\mathrm{Na}(\mathrm{AA})$ & 13.820 & 13.040 \\
\hline Li (ICP) & $<0.001$ & $<0.001$ \\
\hline $\mathrm{Ni}(\mathrm{ICP})$ & 1.781 & 1.961 \\
\hline $\mathrm{Ni}(\mathrm{AA})$ & 1.837 & 2.133 \\
\hline Si (ICP) & 15.715 & 16.023 \\
\hline Si (AA) & 18.260 & 17.710 \\
\hline $\mathrm{Cr}(\mathrm{ICP})$ & $<0.004$ & $<0.004$ \\
\hline B (ICP) & 0.073 & $<0.004$ \\
\hline U (Chemcheck) & 2.880 & 3.130 \\
\hline $\mathrm{Sr}(\mathrm{ICP})$ & $<0.000$ & $<0.000$ \\
\hline $\operatorname{Zr}(\mathrm{ICP})$ & $<0.002$ & $<0.002$ \\
\hline Ti (ICP) & 0.028 & 0.019 \\
\hline$K(A A)$ & 0.530 & 0.630 \\
\hline$P(I C P)^{\star \star \star}$ & 1.624 & 0.651 \\
\hline$P(\text { Calc IC })^{\star *}$ & 1.931 & 1.994 \\
\hline $\mathrm{Ba}(\mathrm{ICP})$ & $<0.00$ & $<0.00$ \\
\hline $\mathrm{Pb}(\mathrm{ICP})$ & $<0.020$ & 0.156 \\
\hline Mo (ICP) & $<0.004$ & $<0.004$ \\
\hline $\mathrm{Zn}(\mathrm{ICP})$ & 0.171 & 0.181 \\
\hline $\mathrm{Cu}(\mathrm{ICP})$ & $<0.001$ & 0.172 \\
\hline F (ISE) & 0.050 & 0.050 \\
\hline Cl (ISE) & 0.700 & 0.650 \\
\hline SO4 (IC) & 0.271 & 0.204 \\
\hline NO3 (IC) & 15.260 & 15.010 \\
\hline $\mathrm{PO} 4(\mathrm{IC})^{\star \star}$ & 5.922 & 6.116 \\
\hline$\%$ SOLIDS $\left(105^{\circ} \mathrm{C}\right)$ & 30.860 & 30.840 \\
\hline$\%$ SOLIDS $\left(90^{\circ} \mathrm{C}\right)$ & $\mathrm{N} / \mathrm{A}$ & $\mathrm{N} / \mathrm{A}$ \\
\hline Moles of $\mathrm{Na}$ & 0.601 & 0.567 \\
\hline Moles of NO3 & 0.246 & 0.242 \\
\hline Moles of $\mathrm{Cl}$ & 0.020 & 0.018 \\
\hline
\end{tabular}

\begin{tabular}{|c|c|}
\hline $\begin{array}{r}\text { TANK } 7 \\
\text { AVERAGE }\end{array}$ & $\begin{array}{r}\text { TANK } 7 \\
\text { STANDARD } \\
\text { DEVIATION }\end{array}$ \\
\hline 6.392 & 0.222 \\
\hline 0.420 & 0.220 \\
\hline 0.529 & 0.102 \\
\hline 0.125 & 0.014 \\
\hline 0.005 & 0.002 \\
\hline 12.292 & 0.808 \\
\hline 13.430 & 0.552 \\
\hline$<0.001$ & \\
\hline 1.871 & 0.127 \\
\hline 1.985 & 0.209 \\
\hline 15.869 & 0.218 \\
\hline 17.985 & 0.389 \\
\hline$<0.004$ & \\
\hline 0.037 & \\
\hline 3.005 & 0.177 \\
\hline$<0.000$ & \\
\hline$<0.002$ & \\
\hline 0.024 & 0.006 \\
\hline 0.580 & 0.071 \\
\hline 1.137 & 0.688 \\
\hline 1.963 & 0.045 \\
\hline 0.000 & \\
\hline 0.156 & \\
\hline$<0.004$ & \\
\hline 0.176 & 0.007 \\
\hline 0.172 & \\
\hline 0.050 & 0.000 \\
\hline 0.675 & 0.035 \\
\hline 0.237 & 0.047 \\
\hline 15.135 & 0.177 \\
\hline 6.019 & 0.137 \\
\hline 30.850 & 0.014 \\
\hline $\mathrm{N} / \mathrm{A}$ & $\mathrm{N} / \mathrm{A}$ \\
\hline 0.584 & 0.024 \\
\hline 0.244 & 0.003 \\
\hline 0.019 & 0.001 \\
\hline
\end{tabular}

*AA Silicon values in italics from $\mathrm{HCl} / \mathrm{HF}$ dissolution; others from $\mathrm{Na} 2 \mathrm{O} 2$ dissolution all anions from $\mathrm{Na} 2 \mathrm{O} 2$ fusion with $\mathrm{H} 2 \mathrm{O}$ uptake (see text)

${ }^{* *}$ water soluble phosphate only; ${ }^{* * *}$ acid soluble phosphate

MASS BALANCE SPECIATION

$\begin{array}{lr}\text { Al(OH)3 } & 13.98 \\ \text { NaNO3 } & 20.75 \\ \text { Filter Aid } & 40.27 \\ \text { Na6U7O24 } & 3.95 \\ \text { Ca-Zeolite-A } & 3.86 \\ \text { AlPO4 } & 3.49 \\ \text { SUM } & 86.291 \\ \text { EXCESS moles Na over } & \\ \text { NaNO3 and } \mathrm{Na}-\mathrm{U}= & 0.329\end{array}$




\begin{tabular}{|c|c|c|c|c|}
\hline Tank 8 (P42) & TK-8-P42-1 & TK-8-P42-2 & TK-8-P42-1 & TK-8-P42-2 \\
\hline ANALYSIS \# & 111480 & 111481 & 21308 & 2130 \\
\hline ANALYSIS DATE & $3 / 1 / 88$ & $3 / 1 / 88$ & $11 / 1 / 88$ & $11 / 1 / \varepsilon$ \\
\hline RECORDED & DPSTN 4475 & DPSTN 4475 & DPSTN 4725 & DPSTN 472 \\
\hline $\mathrm{Al}(\mathrm{ICP})$ & 10.900 & 10.700 & 10.780 & 10.77 \\
\hline $\mathrm{Ca}(\mathrm{ICP})$ & 0.183 & 0.183 & 0.340 & 0.56 \\
\hline $\mathrm{Fe}(\mathrm{ICP})$ & $<0.004$ & $<0.004$ & 0.440 & 0.4 \\
\hline $\mathrm{Mg}(\mathrm{ICP})$ & 0.096 & 0.087 & 0.130 & 0.16 \\
\hline $\mathrm{Mn}(\mathrm{ICP})$ & $<0.004$ & $<0.004$ & 0.440 & 0.7 \\
\hline $\mathrm{Na}$ (ICP) & & & 7.590 & \\
\hline $\mathrm{Na}(\mathrm{AA})$ & 6.810 & 6.730 & 8.220 & \\
\hline Li (ICP) & $<0.002$ & $<0.002$ & $<0.002$ & \\
\hline $\mathrm{Ni}$ (ICP) & & & 0.740 & 0.7 \\
\hline $\mathrm{Ni}(\mathrm{AA})$ & & & 0.959 & \\
\hline Si (ICP) & 10.900 & 10.500 & 11.390 & 11.5 \\
\hline Si (AA) & 14.260 & 14.860 & 14.060 & 15.0 \\
\hline $\mathrm{Cr}(\mathrm{ICP})$ & 0.004 & $<0.004$ & 0.020 & 0.0 \\
\hline B (ICP) & $<0.002$ & $<0.002$ & 0.010 & 0.0 \\
\hline U (D-G) & 6.840 & 6.023 & & \\
\hline $\operatorname{Sr}(\mathrm{ICP})$ & 0.004 & 0.004 & $<0.0005$ & 0.0 \\
\hline $\mathrm{Zr}(\mathrm{ICP})$ & $<0.002$ & $<0.002$ & 0.010 & 0.0 \\
\hline $\mathrm{Ti}(\mathrm{ICP})$ & 0.022 & 0.020 & 0.030 & \\
\hline $\mathrm{K}(\mathrm{AA})$ & & & 0.124 & \\
\hline$P(I C P)^{\star \star \star}$ & 2.730 & 2.780 & 1.350 & \\
\hline$P(\text { Calc IC })^{\star *}$ & 0.964 & 1.023 & & \\
\hline $\mathrm{Ba}(\mathrm{ICP})$ & 0.049 & 0.051 & $<0.001$ & $<0.0$ \\
\hline $\mathrm{Pb}(\mathrm{ICP})$ & $<0.012$ & $<0.012$ & 0.150 & \\
\hline Mo (ICP) & $<0.004$ & $<0.004$ & 0.010 & 0.0 \\
\hline $\mathrm{Zn}(\mathrm{ICP})$ & $<0.004$ & $<0.004$ & 0.770 & $1.2 \varepsilon$ \\
\hline $\mathrm{Cu}(\mathrm{ICP})$ & 0.016 & 0.011 & 0.040 & 0.0 \\
\hline F (ISE) & $\mathrm{N} / \mathrm{A}$ & $\mathrm{N} / \mathrm{A}$ & & \\
\hline $\mathrm{Cl}$ (ISE) & 0.059 & 0.060 & & \\
\hline SO4 (IC) & $<0.5$ & $<0.5$ & & \\
\hline NO3 (IC) & 15.810 & 16.750 & & \\
\hline $\mathrm{PO} 4(\mathrm{IC})^{\star *}$ & 2.955 & 3.136 & & \\
\hline$\%$ SOLIDS $\left(105^{\circ} \mathrm{C}\right)$ & 34.480 & & & \\
\hline$\%$ SOLIDS $\left(90^{\circ} \mathrm{C}\right)$ & 31.650 & & & \\
\hline Moles of $\mathrm{Na}$ & 0.296 & 0.293 & 0.358 & \\
\hline Moles of NO3 & 0.255 & 0.270 & & \\
\hline Moles of $\mathrm{Cl}$ & 0.002 & 0.002 & & \\
\hline
\end{tabular}

*AA Silicon values in italics from $\mathrm{HCl} / \mathrm{HF}$ dissolution; others from $\mathrm{Na} 2 \mathrm{O} 2$ dissolution all anions from $\mathrm{Na} 2 \mathrm{O} 2$ fusion with $\mathrm{H} 2 \mathrm{O}$ uptake (see text)

${ }^{* *}$ water soluble phosphate only; ${ }^{* * *}$ acid soluble phosphate

\section{TANK 8-P42 AVERAGE \\ TANK 8-P42 STANDARD DEVIATION}

\begin{tabular}{rl}
10.788 & 0.083 \\
0.317 & 0.178 \\
0.420 & 0.028 \\
0.118 & 0.033 \\
0.605 & 0.233 \\
6.720 & 1.230 \\
7.253 & 0.684 \\
$<0.002$ & \\
0.740 & 0.000 \\
0.956 & 0.005 \\
11.075 & 0.465 \\
14.545 & 0.686 \\
0.015 & 0.009 \\
0.010 & 0.000 \\
6.432 & 0.578 \\
0.006 & 0.003 \\
0.010 & 0.000 \\
0.028 & 0.009 \\
0.123 & 0.002 \\
2.043 & 0.823 \\
0.993 & 0.042 \\
0.050 & 0.001 \\
0.185 & 0.049 \\
0.010 & 0.000 \\
1.025 & 0.361 \\
0.022 & 0.013 \\
$\mathrm{~N} / \mathrm{A}$ & \\
0.059 & 0.001 \\
$<0.5$ & \\
16.280 & 0.665 \\
3.046 & 0.128 \\
34.480 & \\
31.650 & \\
0.315 & 0.030 \\
0.263 & 0.011 \\
0.002 & 0.000 \\
& \\
\hline
\end{tabular}

24.81

22.32

32.64

8.45

2.91

6.26

97.39

0.030 


\begin{tabular}{|c|c|c|c|c|}
\hline Tank 8 (P43) & TK-8-P43-1 & TK-8-P43-2 & TK-8-P43-1 & TK-8-P43-2 \\
\hline ANALYSIS \# & 111482 & 111483 & 21310 & 2131 \\
\hline ANALYSIS DATE & $3 / 1 / 88$ & $3 / 1 / 88$ & $11 / 1 / 88$ & $11 / 1 / \varepsilon$ \\
\hline RECORDED & DPSTN 4475 & DPSTN 4475 & DPSTN 4725 & DPSTN 472 \\
\hline $\mathrm{Al}(\mathrm{ICP})$ & 10.700 & 9.500 & 11.310 & 11.21 \\
\hline $\mathrm{Ca}(\mathrm{ICP})$ & 0.195 & 0.291 & 0.340 & 0.36 \\
\hline $\mathrm{Fe}(\mathrm{ICP})$ & 0.229 & $<0.004$ & 0.460 & 0.4 \\
\hline $\mathrm{Mg}(\mathrm{ICP})$ & 0.122 & 0.099 & 0.140 & 0.1 \\
\hline $\mathrm{Mn}(\mathrm{ICP})$ & 0.065 & 0.014 & 0.430 & 0.45 \\
\hline $\mathrm{Na}$ (ICP) & & & 6.960 & 7.6 \\
\hline $\mathrm{Na}(\mathrm{AA})$ & 7.530 & 3.650 & 9.130 & \\
\hline Li (ICP) & $<0.002$ & $<0.002$ & $<0.002$ & \\
\hline $\mathrm{Ni}$ (ICP) & & & 0.710 & \\
\hline $\mathrm{Ni}(\mathrm{AA})$ & & & 0.948 & 1.10 \\
\hline Si (ICP) & 11.700 & 10.400 & 12.090 & 11.9 \\
\hline Si (AA) & 14.590 & 13.360 & 15.140 & 14.6 \\
\hline $\mathrm{Cr}(\mathrm{ICP})$ & $<0.004$ & $<0.004$ & 0.020 & 0.0 \\
\hline B (ICP) & $<0.002$ & $<0.002$ & 0.010 & \\
\hline U (D-G) & 5.960 & 1.710 & & \\
\hline $\operatorname{Sr}(\mathrm{ICP})$ & 0.004 & 0.006 & $<0.0005$ & $<0.00$ \\
\hline $\mathrm{Zr}(\mathrm{ICP})$ & 0.007 & $<0.002$ & 0.010 & 0.0 \\
\hline $\mathrm{Ti}(\mathrm{ICP})$ & 0.031 & 0.025 & 0.030 & \\
\hline$K(A A)$ & & & 0.118 & \\
\hline$P(I C P)^{\star \star \star}$ & 2.330 & 2.040 & 1.330 & \\
\hline$P(\text { Calc IC })^{\star *}$ & 0.955 & 0.950 & & \\
\hline $\mathrm{Ba}(\mathrm{ICP})$ & 0.057 & 0.054 & $<0.001$ & $<0.0$ \\
\hline $\mathrm{Pb}(\mathrm{ICP})$ & 0.042 & 0.026 & 0.140 & \\
\hline Mo (ICP) & 0.005 & $<0.004$ & 0.010 & 0.0 \\
\hline $\mathrm{Zn}(\mathrm{ICP})$ & 0.177 & $<0.002$ & 0.730 & 0.7 \\
\hline $\mathrm{Cu}(\mathrm{ICP})$ & 0.017 & 0.012 & 0.030 & 0.0 \\
\hline F (ISE) & $\mathrm{N} / \mathrm{A}$ & $\mathrm{N} / \mathrm{A}$ & & \\
\hline Cl (ISE) & 0.062 & 0.057 & & \\
\hline SO4 (IC) & $<1.0$ & $<1.0$ & & \\
\hline NO3 (IC) & 17.450 & 15.495 & & \\
\hline $\mathrm{PO} 4(\mathrm{IC})^{\star *}$ & 2.930 & 2.913 & & \\
\hline$\%$ SOLIDS $\left(105^{\circ} \mathrm{C}\right)$ & 41.990 & & & \\
\hline$\%$ SOLIDS $\left(90^{\circ} \mathrm{C}\right)$ & 33.120 & & & \\
\hline Moles of $\mathrm{Na}$ & 0.328 & 0.159 & 0.397 & 0.3 \\
\hline Moles of NO3 & 0.281 & 0.250 & & \\
\hline Moles of $\mathrm{Cl}$ & 0.002 & 0.002 & & \\
\hline
\end{tabular}

*AA Silicon values in italics from $\mathrm{HCl} / \mathrm{HF}$ dissolution; others from $\mathrm{Na} 2 \mathrm{O} 2$ dissolution all anions from $\mathrm{Na} 2 \mathrm{O} 2$ fusion with $\mathrm{H} 2 \mathrm{O}$ uptake (see text)

${ }^{* *}$ water soluble phosphate only; ${ }^{* * *}$ acid soluble phosphate

\section{TANK 8-P43 AVERAGE}

$\begin{array}{rl}10.680 & 0.831 \\ 0.297 & 0.074 \\ 0.383 & 0.133 \\ 0.125 & 0.019 \\ 0.240 & 0.232 \\ 7.300 & 0.481 \\ 6.860 & 2.308 \\ <0.002 & \\ 0.715 & 0.007 \\ 1.024 & 0.107 \\ 11.528 & 0.768 \\ 14.885 & 0.361 \\ 0.020 & 0.000 \\ 0.010 & 0.000 \\ 3.835 & 3.005 \\ 0.005 & 0.001 \\ 0.009 & 0.002 \\ 0.029 & 0.003 \\ 0.119 & 0.001 \\ 1.750 & 0.516 \\ 0.953 & 0.004 \\ 0.056 & 0.002 \\ 0.090 & 0.065 \\ 0.008 & 0.003 \\ 0.562 & 0.335 \\ 0.022 & 0.009 \\ \mathrm{~N} / \mathrm{A} & \\ 0.059 & 0.004 \\ <1.0 & \\ 16.473 & 1.382 \\ 2.922 & 0.012 \\ 41.990 & \\ 33.120 & \\ 0.298 & 0.100 \\ 0.266 & 0.022 \\ 0.002 & 0.000 \\ & \end{array}$

25.31

22.58

33.49

5.04

2.72

5.37

94.52

0.019 


\begin{tabular}{|c|c|c|}
\hline Tank 10 & TK-10-1 & TK-10-2 \\
\hline ANALYSIS \# & 200076568 & 200076569 \\
\hline ANALYSIS DATE & $5 / 12 / 92$ & $5 / 12 / 92$ \\
\hline RECORDED & DPSTN 4725 & DPSTN 4725 \\
\hline $\mathrm{Al}(\mathrm{ICP})$ & 8.613 & 9.179 \\
\hline $\mathrm{Ca}(\mathrm{ICP})$ & 0.322 & 0.379 \\
\hline $\mathrm{Fe}(\mathrm{ICP})$ & 0.892 & 0.847 \\
\hline $\mathrm{Mg}(\mathrm{ICP})$ & 0.105 & 0.138 \\
\hline $\mathrm{Mn}(\mathrm{ICP})$ & 0.035 & 0.035 \\
\hline $\mathrm{Na}$ (ICP) & 7.594 & 6.798 \\
\hline $\mathrm{Na}(\mathrm{AA})$ & 7.860 & 7.006 \\
\hline Li (ICP) & $<0.001$ & $<0.001$ \\
\hline $\mathrm{Ni}(\mathrm{ICP})$ & 0.066 & 0.062 \\
\hline $\mathrm{Ni}(\mathrm{AA})$ & $<0.06$ & $<0.06$ \\
\hline Si (ICP) & 23.950 & 25.620 \\
\hline Si (AA) & 26.720 & 28.170 \\
\hline $\mathrm{Cr}(\mathrm{ICP})$ & $<0.004$ & $<0.004$ \\
\hline B (ICP) & $<0.004$ & $<0.004$ \\
\hline U (Chemcheck) & 0.040 & 0.050 \\
\hline $\mathrm{Sr}(\mathrm{ICP})$ & 0.000 & 0.000 \\
\hline $\mathrm{Zr}(\mathrm{ICP})$ & $<0.002$ & $<0.002$ \\
\hline $\mathrm{Ti}(\mathrm{ICP})$ & 0.027 & 0.026 \\
\hline$K(\mathrm{AA})$ & 2.500 & 2.710 \\
\hline$P(I C P)^{\star \star \star}$ & 0.976 & 1.085 \\
\hline$P(\text { Calc IC })^{\star \star}$ & 0.995 & 1.076 \\
\hline $\mathrm{Ba}(\mathrm{ICP})$ & 0.000 & 0.000 \\
\hline $\mathrm{Pb}(\mathrm{ICP})$ & 0.071 & $<0.02$ \\
\hline Mo (ICP) & $<0.004$ & $<0.004$ \\
\hline Zn (ICP) & 0.169 & 0.175 \\
\hline $\mathrm{Cu}(\mathrm{ICP})$ & $<0.001$ & 0.005 \\
\hline F (ISE) & 0.060 & 0.060 \\
\hline $\mathrm{Cl}$ (ISE) & 0.360 & 0.260 \\
\hline SO4 (IC) & $<0.2$ & $<0.2$ \\
\hline NO3 (IC) & 7.640 & 8.229 \\
\hline $\mathrm{PO} 4(\mathrm{IC})^{\star *}$ & 3.050 & 3.300 \\
\hline$\%$ SOLIDS $\left(105^{\circ} \mathrm{C}\right)$ & 17.520 & 17.600 \\
\hline$\%$ SOLIDS $\left(90^{\circ} \mathrm{C}\right)$ & $\mathrm{N} / \mathrm{A}$ & $N / A$ \\
\hline Moles of $\mathrm{Na}$ & 0.342 & 0.305 \\
\hline Moles of NO3 & 0.123 & 0.133 \\
\hline Moles of $\mathrm{Cl}$ & 0.010 & 0.007 \\
\hline
\end{tabular}

TANK 10 AVERAGE

8.896

0.351

0.870

0.122

0.035

7.196

7.433

$<0.001$

0.064

$<0.06$

24.785

27.445

$<0.004$

$<0.004$

0.045

0.000

$<0.002$

0.027

2.605

1.031

1.035

0.000

0.071

0.172

0.005

0.060

0.310

$<0.2$

7.935

3.175

17.560

N/A

0.323

0.128

0.009
TANK 10

STANDARD DEVIATION

0.400

0.040

0.032

0.023

0.000

0.563

0.604

0.003

1.181

1.025

0.007

0.000

0.001

0.148

0.077

0.058

0.004

0.000

0.071

0.416

0.177

0.057

0.026

0.007

0.002

*AA Silicon values in italics from $\mathrm{HCl} / \mathrm{HF}$ dissolution; others from $\mathrm{Na} 2 \mathrm{O} 2$ dissolution all anions from $\mathrm{Na} 2 \mathrm{O} 2$ fusion with $\mathrm{H} 2 \mathrm{O}$ uptake (see text)

** water soluble phosphate only; ${ }^{* * *}$ acid soluble phosphate

MASS BALANCE SPECIATION

$\begin{array}{lr}\text { Al }(\mathrm{OH}) 3 & 21.76 \\ \text { NaNO3 } & 10.88 \\ \text { Filter Aid } & 62.39 \\ \text { Na6U7O24 } & 0.06 \\ \text { Ca-Zeolite-A } & 3.22 \\ \text { AlPO4 } & 3.16 \\ \text { SUM } & 101.469 \\ \text { EXCESS moles Na over } & \\ \text { NaNO3 and } \mathrm{Na}-\mathrm{U}= & 0.195\end{array}$




\begin{tabular}{|c|c|c|}
\hline New Tank 10 & NEW TK10-A & NEW TK10-E \\
\hline ANALYSIS \# & 300011338 & 30001133 \\
\hline ANALYSIS DATE & $7 / 6 / 93$ & $7 / 6 /$ \\
\hline RECORDED & DPSTN 4695 & DPSTN 46 \\
\hline $\mathrm{Al}(\mathrm{ICP})$ & 9.672 & 9.6 \\
\hline $\mathrm{Ca}(\mathrm{ICP})$ & 0.403 & 0.4 \\
\hline $\mathrm{Fe}(\mathrm{ICP})$ & 0.904 & 1.1 \\
\hline $\mathrm{Mg}(\mathrm{ICP})$ & 0.120 & 0.1 \\
\hline $\mathrm{Mn}(\mathrm{ICP})$ & 0.048 & 0.0 \\
\hline $\mathrm{Na}(\mathrm{ICP})$ & 5.255 & 5.0 \\
\hline $\mathrm{Na}(\mathrm{AA})$ & 5.198 & \\
\hline Li (ICP) & 0.004 & \\
\hline Ni (ICP) & 0.080 & \\
\hline Ni (AA) & 0.052 & \\
\hline Si (ICP) & 25.377 & 24.9 \\
\hline Si (AA) & 24.880 & 24.8 \\
\hline $\mathrm{Cr}(\mathrm{ICP})$ & 0.009 & \\
\hline $\mathrm{B}(\mathrm{ICP})$ & $<0.004$ & $<0.0$ \\
\hline U (Chemcheck) & 0.295 & \\
\hline $\operatorname{Sr}(I C P)$ & 0.002 & \\
\hline $\mathrm{Zr}(\mathrm{ICP})$ & 0.011 & 0.0 \\
\hline $\mathrm{Ti}(\mathrm{ICP})$ & 0.060 & \\
\hline$K(A A)$ & 2.046 & \\
\hline $\mathbf{P}(\mathrm{ICP})^{\star \star \star}$ & 1.081 & \\
\hline$P(\text { Calc IC })^{\star *}$ & 0.984 & \\
\hline $\mathrm{Ba}(\mathrm{ICP})$ & 0.017 & \\
\hline $\mathrm{Pb}(\mathrm{ICP})$ & 0.037 & \\
\hline Mo (ICP) & 0.006 & \\
\hline $\mathrm{Zn}(\mathrm{ICP})$ & 0.465 & \\
\hline $\mathrm{Cu}(\mathrm{ICP})$ & 0.095 & \\
\hline $\mathrm{F}(\mathrm{ISE})$ & 0.920 & \\
\hline $\mathrm{Cl}$ (ISE) & 0.121 & 0.1 \\
\hline SO4 (IC) & 0.178 & 0.4 \\
\hline NO3 (IC) & 6.082 & 6.3 \\
\hline $\mathrm{PO} 4(\mathrm{IC})^{\star *}$ & 3.016 & 3.0 \\
\hline$\%$ SOLIDS $\left(105^{\circ} \mathrm{C}\right)$ & 19.960 & 19.9 \\
\hline$\%$ SOLIDS $\left(90^{\circ} \mathrm{C}\right)$ & 5.380 & \\
\hline Moles of $\mathrm{Na}$ & 0.226 & \\
\hline Moles of $\mathrm{NO} 3$ & 0.098 & \\
\hline Moles of $\mathrm{Cl}$ & 0.003 & \\
\hline
\end{tabular}

$\begin{array}{rr}\text { NEW TANK } & \text { TANK 10 } \\ \text { AVERAGE } & \text { STANDARD } \\ & \text { DEVIATION } \\ & \\ 9.642 & 0.042 \\ 0.425 & 0.031 \\ 1.046 & 0.201 \\ 0.122 & 0.003 \\ 0.049 & 0.001 \\ 5.132 & 0.175 \\ 5.233 & 0.049 \\ <0.001 & \\ 0.081 & 0.001 \\ <0.06 & \\ 25.144 & 0.330 \\ 24.845 & 0.049 \\ <0.004 & \\ <0.004 & \\ 0.222 & 0.104 \\ 0.002 & 0.000 \\ <0.002 & \\ 0.062 & 0.003 \\ 2.053 & 0.010 \\ 0.959 & 0.173 \\ 0.997 & 0.019 \\ 0.016 & 0.001 \\ 0.032 & 0.008 \\ 0.005 & 0.001 \\ 0.464 & 0.002 \\ 0.065 & 0.042 \\ 1.189 & 0.381 \\ 0.134 & 0.019 \\ 0.332 & 0.218 \\ 6.202 & 0.170 \\ 3.057 & 0.058 \\ 19.970 & 0.014 \\ 5.380 & \\ 0.228 & 0.002 \\ 0.100 & 0.003 \\ 0.004 & 0.001\end{array}$

${ }^{*}$ AA Silicon values in italics from $\mathrm{HCl} / \mathrm{HF}$ dissolution; others from $\mathrm{Na2O} 2$ dissolution all anions from $\mathrm{Na} 2 \mathrm{O} 2$ fusion with $\mathrm{H} 2 \mathrm{O}$ uptake (see text)

${ }^{* *}$ water soluble phosphate only; ${ }^{* * *}$ acid soluble phosphate

MASS BALANCE SPECIATION

$\mathrm{Al}(\mathrm{OH}) 3$

23.81

$\mathrm{NaNO} 3$

8.50

Filter Aid

56.13

Na6U7O24

0.29

Ca-Zeolite-A

3.91

AIPO4

2.94

SUM

95.58

EXCESS moles $\mathrm{Na}$ over

$\mathrm{NaNO} 3$ and $\mathrm{Na}-\mathrm{U}=$

0.127 
This page intentionally left blank. 


\section{APPENDIX II M-AREA VIRGIN FILTER AID ANALYSES}

SAMPLE ID = DIATOMACEOUS EARTH (DPSTN=4725, ADS\# 100021313-AFTER DRYING AT $600^{\circ} \mathrm{C}$ )

\begin{tabular}{|c|c|c|c|c|c|c|c|}
\hline & $\begin{array}{l}\text { ELEMENT } \\
\text { WT\% }\end{array}$ & $\begin{array}{l}\text { GRAV } \\
\text { FACTOR }\end{array}$ & $\begin{array}{l}\text { OXIDE } \\
\text { WT\% }\end{array}$ & $\begin{array}{c}\text { NORM OXIDE } \\
\text { WT\% }\end{array}$ & M.W. & $\begin{array}{c}\text { MOLE } \\
\text { FRACTION }\end{array}$ & $\begin{array}{l}\text { NORM OXIDE } \\
\text { MOLE \% }\end{array}$ \\
\hline Al2O3 & 8.5100 & 1.8895 & 16.0796 & 15.5271 & 101.9600 & 0.1577 & 8.5292 \\
\hline $\mathrm{CaO}$ & 0.6500 & 1.3992 & 0.9095 & 0.8782 & 56.0794 & 0.0162 & 0.8771 \\
\hline $\mathrm{Fe} 203$ & 0.6400 & 1.4297 & 0.9150 & 0.8836 & 159.6922 & 0.0057 & 0.3099 \\
\hline $\mathrm{FeO}$ & & 1.2865 & 0.0000 & 0.0000 & 71.8464 & 0.0000 & 0.0000 \\
\hline $\mathrm{MgO}$ & 0.0800 & 1.6583 & 0.1327 & 0.1281 & 40.3114 & 0.0033 & 0.1780 \\
\hline $\mathrm{MnO} 2$ & 0.5700 & 1.5825 & 0.9020 & 0.8710 & 70.9374 & 0.0127 & 0.6877 \\
\hline $\mathrm{Na} 2 \mathrm{O}$ & 2.4300 & 1.3480 & 3.2756 & 3.1631 & 61.9790 & 0.0529 & 2.8583 \\
\hline Li2O & & 2.1525 & 0.0000 & 0.0000 & 29.8774 & 0.0000 & 0.0000 \\
\hline $\mathrm{NiO}$ & 0.2400 & 1.2726 & 0.3054 & 0.2949 & 74.7094 & 0.0041 & 0.2211 \\
\hline $\mathrm{SiO} 2$ & 31.4700 & 2.1393 & 67.3238 & 65.0102 & 60.0848 & 1.1205 & 60.5987 \\
\hline Cr2O3 & & 1.4616 & 0.0000 & 0.0000 & 151.9974 & 0.0000 & 0.0000 \\
\hline B203 & & 3.2201 & 0.0000 & 0.0000 & 69.6204 & 0.0000 & 0.0000 \\
\hline UO2 & & 1.1344 & 0.0000 & 0.0000 & 270.0388 & 0.0000 & 0.0000 \\
\hline ThO2 & & 1.1379 & 0.0000 & 0.0000 & 264.0400 & 0.0000 & 0.0000 \\
\hline $\mathrm{SrO}$ & & 1.1826 & 0.0000 & 0.0000 & 103.6194 & 0.0000 & 0.0000 \\
\hline $\mathrm{ZrO} 2$ & 0.0100 & 1.3508 & 0.0135 & 0.0130 & 123.2188 & 0.0001 & 0.0059 \\
\hline TiO2 & 0.0400 & 1.6680 & 0.0667 & 0.0644 & 79.8988 & 0.0008 & 0.0452 \\
\hline K2O & 3.7000 & 1.2046 & 4.4570 & 4.3039 & 94.2034 & 0.0473 & 2.5588 \\
\hline Cs2O & & 1.0602 & 0.0000 & 0.0000 & 281.8094 & 0.0000 & 0.0000 \\
\hline $\mathrm{Sb} 2 \mathrm{O} 3$ & & 1.1970 & 0.0000 & 0.0000 & 291.4982 & 0.0000 & 0.0000 \\
\hline P2O5 & 0.1900 & 2.2910 & 0.4353 & 0.4203 & 141.9370 & 0.0031 & 0.1659 \\
\hline $\mathrm{Nd} 2 \mathrm{O} 3$ & & 1.1660 & 0.0000 & 0.0000 & 336.4782 & 0.0000 & 0.0000 \\
\hline La2O3 & & 1.1728 & 0.0000 & 0.0000 & 325.8100 & 0.0000 & 0.0000 \\
\hline Y2O3 & & 1.2699 & 0.0000 & 0.0000 & 225.8082 & 0.0000 & 0.0000 \\
\hline $\mathrm{BaO}$ & 0.0300 & 1.1165 & 0.0335 & 0.0323 & 153.3394 & 0.0002 & 0.0118 \\
\hline $\mathrm{PbO}$ & 0.1800 & 1.0772 & 0.1939 & 0.1872 & 223.1900 & 0.0009 & 0.0470 \\
\hline $\mathrm{CeO} 2$ & & 1.2284 & 0.0000 & 0.0000 & 172.1200 & 0.0000 & 0.0000 \\
\hline MoO3 & & 1.5003 & 0.0000 & 0.0000 & 143.9382 & 0.0000 & 0.0000 \\
\hline $\mathrm{ZnO}$ & 0.9000 & 1.2447 & 1.1202 & 1.0817 & 81.3800 & 0.0138 & 0.7445 \\
\hline $\mathrm{CuO}$ & 0.0200 & 1.2518 & 0.0250 & 0.0242 & 79.5454 & 0.0003 & 0.0170 \\
\hline $\mathrm{H} 2 \mathrm{O}$ & 7.3700 & 1.0000 & 7.3700 & 7.1167 & 18.0000 & 0.4094 & 22.1439 \\
\hline SUMS & & & 103.5589 & 100.0000 & & 1.8490 & 100.0000 \\
\hline
\end{tabular}


SAMPLE ID = PERFLO (DPSTN=4725, ADS\# 100021312-AFTER DRYING AT 600 ${ }^{\circ}$ )

\begin{tabular}{|c|c|c|c|c|c|c|}
\hline $\begin{array}{l}\text { ELEMENT } \\
\text { WT\% }\end{array}$ & $\begin{array}{l}\text { GRAV } \\
\text { FACTOR }\end{array}$ & $\begin{array}{l}\text { OXIDE } \\
\text { WT\% }\end{array}$ & $\begin{array}{c}\text { NORM OXIDE } \\
\text { WT\% }\end{array}$ & M.W. & $\begin{array}{c}\text { MOLE } \\
\text { FRACTION }\end{array}$ & $\begin{array}{l}\text { NORM OXIDE } \\
\text { MOLE \% }\end{array}$ \\
\hline 6.5400 & 1.8895 & 12.3573 & 12.5865 & 101.9600 & 0.1212 & 8.0597 \\
\hline 0.6600 & 1.3992 & 0.9235 & 0.9406 & 56.0794 & 0.0165 & 1.0951 \\
\hline \multirow{2}{*}{1.1700} & 1.4297 & 1.6727 & 1.7038 & 159.6922 & 0.0105 & 0.6966 \\
\hline & 1.2865 & 0.0000 & 0.0000 & 71.8464 & 0.0000 & 0.0000 \\
\hline 0.0700 & 1.6583 & 0.1161 & 0.1182 & 40.3114 & 0.0029 & 0.1915 \\
\hline 0.3700 & 1.5825 & 0.5855 & 0.5964 & 70.9374 & 0.0083 & 0.5489 \\
\hline \multirow[t]{3}{*}{2.6300} & 1.3480 & 3.5452 & 3.6110 & 61.9790 & 0.0572 & 3.8039 \\
\hline & 2.1525 & 0.0000 & 0.0000 & 29.8774 & 0.0000 & 0.0000 \\
\hline & 1.2726 & 0.0000 & 0.0000 & 74.7094 & 0.0000 & 0.0000 \\
\hline \multirow[t]{6}{*}{34.1000} & 2.1393 & 72.9501 & 74.3028 & 60.0848 & 1.2141 & 80.7398 \\
\hline & 1.4616 & 0.0000 & 0.0000 & 151.9974 & 0.0000 & 0.0000 \\
\hline & 3.2201 & 0.0000 & 0.0000 & 69.6204 & 0.0000 & 0.0000 \\
\hline & 1.1344 & 0.0000 & 0.0000 & 270.0388 & 0.0000 & 0.0000 \\
\hline & 1.1379 & 0.0000 & 0.0000 & 264.0400 & 0.0000 & 0.0000 \\
\hline & 1.1826 & 0.0000 & 0.0000 & 103.6194 & 0.0000 & 0.0000 \\
\hline 0.0100 & 1.3508 & 0.0135 & 0.0138 & 123.2188 & 0.0001 & 0.0073 \\
\hline 0.0400 & 1.6680 & 0.0667 & 0.0680 & 79.8988 & 0.0008 & 0.0555 \\
\hline \multirow[t]{3}{*}{4.0000} & 1.2046 & 4.8184 & 4.9077 & 94.2034 & 0.0511 & 3.4014 \\
\hline & 1.0602 & 0.0000 & 0.0000 & 281.8094 & 0.0000 & 0.0000 \\
\hline & 1.1970 & 0.0000 & 0.0000 & 291.4982 & 0.0000 & 0.0000 \\
\hline \multirow[t]{4}{*}{0.0400} & 2.2910 & 0.0916 & 0.0933 & 141.9370 & 0.0006 & 0.0429 \\
\hline & 1.1660 & 0.0000 & 0.0000 & 336.4782 & 0.0000 & 0.0000 \\
\hline & 1.1728 & 0.0000 & 0.0000 & 325.8100 & 0.0000 & 0.0000 \\
\hline & 1.2699 & 0.0000 & 0.0000 & 225.8082 & 0.0000 & 0.0000 \\
\hline 0.0400 & 1.1165 & 0.0447 & 0.0455 & 153.3394 & 0.0003 & 0.0194 \\
\hline \multirow[t]{3}{*}{0.0900} & 1.0772 & 0.0969 & 0.0987 & 223.1900 & 0.0004 & 0.0289 \\
\hline & 1.2284 & 0.0000 & 0.0000 & 172.1200 & 0.0000 & 0.0000 \\
\hline & 1.5003 & 0.0000 & 0.0000 & 143.9382 & 0.0000 & 0.0000 \\
\hline 0.5400 & 1.2447 & 0.6721 & 0.6846 & 81.3800 & 0.0083 & 0.5492 \\
\hline 0.0200 & 1.2518 & 0.0250 & 0.0255 & 79.5454 & 0.0003 & 0.0209 \\
\hline \multirow[t]{2}{*}{0.2000} & 1.0000 & 0.2000 & 0.2037 & 18.0000 & 0.0111 & 0.7389 \\
\hline & & 98.1796 & 100.0000 & & 1.5037 & 100.0000 \\
\hline
\end{tabular}


SAMPLE ID = PERLITE 2000X (DPSTN=4725, ADS\# 200002283-AFTER MELTING AT 1150 $)$

\begin{tabular}{|c|c|c|c|c|c|c|c|}
\hline & $\begin{array}{c}\text { ELEMENT } \\
\text { WT\% }\end{array}$ & $\begin{array}{l}\text { GRAV } \\
\text { FACTOR }\end{array}$ & $\begin{array}{l}\text { OXIDE } \\
\text { WT\% }\end{array}$ & $\begin{array}{c}\text { NORM OXIDE } \\
\text { WT\% }\end{array}$ & M.W. & $\begin{array}{c}\text { MOLE } \\
\text { FRACTION }\end{array}$ & $\begin{array}{l}\text { NORM OXIDE } \\
\text { MOLE \% }\end{array}$ \\
\hline $\mathrm{Al} 2 \mathrm{O} 3$ & 6.6040 & 1.8895 & 12.4783 & 12.5644 & 101.9600 & 0.1224 & 8.0277 \\
\hline $\mathrm{CaO}$ & 0.5010 & 1.3992 & 0.7010 & 0.7058 & 56.0794 & 0.0125 & 0.8199 \\
\hline Fe203 & 0.6160 & 1.4297 & 0.8807 & 0.8868 & 159.6922 & 0.0055 & 0.3617 \\
\hline $\mathrm{FeO}$ & & 1.2865 & 0.0000 & 0.0000 & 71.8464 & 0.0000 & 0.0000 \\
\hline $\mathrm{MgO}$ & 0.0630 & 1.6583 & 0.1045 & 0.1052 & 40.3114 & 0.0026 & 0.1700 \\
\hline $\mathrm{MnO} 2$ & 0.0650 & 1.5825 & 0.1029 & 0.1036 & 70.9374 & 0.0015 & 0.0951 \\
\hline $\mathrm{Na} 2 \mathrm{O}$ & 3.3230 & 1.3480 & 4.4794 & 4.5103 & 61.9790 & 0.0723 & 4.7407 \\
\hline Li2O & & 2.1525 & 0.0000 & 0.0000 & 29.8774 & 0.0000 & 0.0000 \\
\hline $\mathrm{NiO}$ & $<0.005$ & 1.2726 & 0.0000 & 0.0000 & 74.7094 & 0.0000 & 0.0000 \\
\hline $\mathrm{SiO} 2$ & 34.9410 & 2.1393 & 74.7493 & 75.2652 & 60.0848 & 1.2441 & 81.6034 \\
\hline $\mathrm{Cr} 2 \mathrm{O} 3$ & & 1.4616 & 0.0000 & 0.0000 & 151.9974 & 0.0000 & 0.0000 \\
\hline B203 & & 3.2201 & 0.0000 & 0.0000 & 69.6204 & 0.0000 & 0.0000 \\
\hline UO2 & & 1.1344 & 0.0000 & 0.0000 & 270.0388 & 0.0000 & 0.0000 \\
\hline ThO2 & & 1.1379 & 0.0000 & 0.0000 & 264.0400 & 0.0000 & 0.0000 \\
\hline $\mathrm{SrO}$ & & 1.1826 & 0.0000 & 0.0000 & 103.6194 & 0.0000 & 0.0000 \\
\hline $\mathrm{ZrO} 2$ & 0.0080 & 1.3508 & 0.0108 & 0.0109 & 123.2188 & 0.0001 & 0.0058 \\
\hline TiO2 & 0.0370 & 1.6680 & 0.0617 & 0.0621 & 79.8988 & 0.0008 & 0.0507 \\
\hline K2O & 4.5020 & 1.2046 & 5.4231 & 5.4605 & 94.2034 & 0.0576 & 3.7761 \\
\hline Cs2O & & 1.0602 & 0.0000 & 0.0000 & 281.8094 & 0.0000 & 0.0000 \\
\hline $\mathrm{Sb} 2 \mathrm{O} 3$ & & 1.1970 & 0.0000 & 0.0000 & 291.4982 & 0.0000 & 0.0000 \\
\hline P2O5 & 0.0130 & 2.2910 & 0.0298 & 0.0300 & 141.9370 & 0.0002 & 0.0138 \\
\hline $\mathrm{Nd} 2 \mathrm{O} 3$ & & 1.1660 & 0.0000 & 0.0000 & 336.4782 & 0.0000 & 0.0000 \\
\hline La2O3 & & 1.1728 & 0.0000 & 0.0000 & 325.8100 & 0.0000 & 0.0000 \\
\hline Y2O3 & & 1.2699 & 0.0000 & 0.0000 & 225.8082 & 0.0000 & 0.0000 \\
\hline $\mathrm{BaO}$ & 0.0360 & 1.1165 & 0.0402 & 0.0405 & 153.3394 & 0.0003 & 0.0172 \\
\hline $\mathrm{PbO}$ & $<0.019$ & 1.0772 & 0.0000 & 0.0000 & 223.1900 & 0.0000 & 0.0000 \\
\hline $\mathrm{CeO} 2$ & & 1.2284 & 0.0000 & 0.0000 & 172.1200 & 0.0000 & 0.0000 \\
\hline MoO3 & & 1.5003 & 0.0000 & 0.0000 & 143.9382 & 0.0000 & 0.0000 \\
\hline $\mathrm{ZnO}$ & 0.1510 & 1.2447 & 0.1879 & 0.1892 & 81.3800 & 0.0023 & 0.1515 \\
\hline $\mathrm{CuO}$ & 0.0200 & 1.2518 & 0.0250 & 0.0252 & 79.5454 & 0.0003 & 0.0206 \\
\hline $\mathrm{H} 2 \mathrm{O}$ & 0.0400 & 1.0000 & 0.0400 & 0.0403 & 18.0000 & 0.0022 & 0.1458 \\
\hline SUMS & & & 99.3146 & 100.0000 & & 1.5245 & 100.0000 \\
\hline
\end{tabular}


SAMPLE ID = PERLITE 200SP (DPSTN=4725, ADS\# 300002284-AFTER MELTING AT $1150^{\circ} \mathrm{C}$ )

\begin{tabular}{|c|c|c|c|c|c|c|c|}
\hline & $\begin{array}{c}\text { ELEMENT } \\
\text { WT\% }\end{array}$ & $\begin{array}{l}\text { GRAV } \\
\text { FACTOR }\end{array}$ & $\begin{array}{l}\text { OXIDE } \\
\text { WT\% }\end{array}$ & $\begin{array}{c}\text { NORM OXIDE } \\
\text { WT\% }\end{array}$ & M.W. & $\begin{array}{c}\text { MOLE } \\
\text { FRACTION }\end{array}$ & $\begin{array}{l}\text { NORM OXIDE } \\
\text { MOLE \% }\end{array}$ \\
\hline $\mathrm{Al} 2 \mathrm{O} 3$ & 6.8450 & 1.8895 & 12.9336 & 13.0212 & 101.9600 & 0.1269 & 8.3010 \\
\hline $\mathrm{CaO}$ & 0.4360 & 1.3992 & 0.6101 & 0.6142 & 56.0794 & 0.0109 & 0.7119 \\
\hline $\mathrm{Fe} 203$ & 0.7100 & 1.4297 & 1.0151 & 1.0220 & 159.6922 & 0.0064 & 0.4160 \\
\hline $\mathrm{FeO}$ & & 1.2865 & 0.0000 & 0.0000 & 71.8464 & 0.0000 & 0.0000 \\
\hline $\mathrm{MgO}$ & 0.1800 & 1.6583 & 0.2985 & 0.3005 & 40.3114 & 0.0074 & 0.4846 \\
\hline $\mathrm{MnO} 2$ & 0.0500 & 1.5825 & 0.0791 & 0.0797 & 70.9374 & 0.0011 & 0.0730 \\
\hline $\mathrm{Na} 2 \mathrm{O}$ & 2.5360 & 1.3480 & 3.4185 & 3.4417 & 61.9790 & 0.0552 & 3.6094 \\
\hline Li2O & & 2.1525 & 0.0000 & 0.0000 & 29.8774 & 0.0000 & 0.0000 \\
\hline $\mathrm{NiO}$ & $<0.005$ & 1.2726 & 0.0000 & 0.0000 & 74.7094 & 0.0000 & 0.0000 \\
\hline $\mathrm{SiO} 2$ & 35.2590 & 2.1393 & 75.4296 & 75.9400 & 60.0848 & 1.2554 & 82.1518 \\
\hline $\mathrm{Cr} 2 \mathrm{O} 3$ & & 1.4616 & 0.0000 & 0.0000 & 151.9974 & 0.0000 & 0.0000 \\
\hline B203 & & 3.2201 & 0.0000 & 0.0000 & 69.6204 & 0.0000 & 0.0000 \\
\hline UO2 & & 1.1344 & 0.0000 & 0.0000 & 270.0388 & 0.0000 & 0.0000 \\
\hline ThO2 & & 1.1379 & 0.0000 & 0.0000 & 264.0400 & 0.0000 & 0.0000 \\
\hline $\mathrm{SrO}$ & & 1.1826 & 0.0000 & 0.0000 & 103.6194 & 0.0000 & 0.0000 \\
\hline $\mathrm{ZrO} 2$ & 0.0080 & 1.3508 & 0.0108 & 0.0109 & 123.2188 & 0.0001 & 0.0057 \\
\hline TiO2 & 0.0620 & 1.6680 & 0.1034 & 0.1041 & 79.8988 & 0.0013 & 0.0847 \\
\hline K2O & 4.1956 & 1.2046 & 5.0540 & 5.0882 & 94.2034 & 0.0537 & 3.5108 \\
\hline Cs2O & & 1.0602 & 0.0000 & 0.0000 & 281.8094 & 0.0000 & 0.0000 \\
\hline $\mathrm{Sb} 2 \mathrm{O} 3$ & & 1.1970 & 0.0000 & 0.0000 & 291.4982 & 0.0000 & 0.0000 \\
\hline P2O5 & 0.0140 & 2.2910 & 0.0321 & 0.0323 & 141.9370 & 0.0002 & 0.0148 \\
\hline $\mathrm{Nd} 2 \mathrm{O} 3$ & & 1.1660 & 0.0000 & 0.0000 & 336.4782 & 0.0000 & 0.0000 \\
\hline La2O3 & & 1.1728 & 0.0000 & 0.0000 & 325.8100 & 0.0000 & 0.0000 \\
\hline Y2O3 & & 1.2699 & 0.0000 & 0.0000 & 225.8082 & 0.0000 & 0.0000 \\
\hline $\mathrm{BaO}$ & 0.0180 & 1.1165 & 0.0201 & 0.0202 & 153.3394 & 0.0001 & 0.0086 \\
\hline $\mathrm{PbO}$ & $<0.020$ & 1.0772 & 0.0000 & 0.0000 & 223.1900 & 0.0000 & 0.0000 \\
\hline $\mathrm{CeO} 2$ & & 1.2284 & 0.0000 & 0.0000 & 172.1200 & 0.0000 & 0.0000 \\
\hline MoO3 & & 1.5003 & 0.0000 & 0.0000 & 143.9382 & 0.0000 & 0.0000 \\
\hline $\mathrm{ZnO}$ & 0.1550 & 1.2447 & 0.1929 & 0.1942 & 81.3800 & 0.0024 & 0.1551 \\
\hline $\mathrm{CuO}$ & & 1.2518 & 0.0000 & 0.0000 & 79.5454 & 0.0000 & 0.0000 \\
\hline $\mathrm{H} 2 \mathrm{O}$ & 0.1300 & 1.0000 & 0.1300 & 0.1309 & 18.0000 & 0.0072 & 0.4726 \\
\hline SUMS & & & 99.3278 & 100.0000 & & 1.5281 & 100.0000 \\
\hline
\end{tabular}

